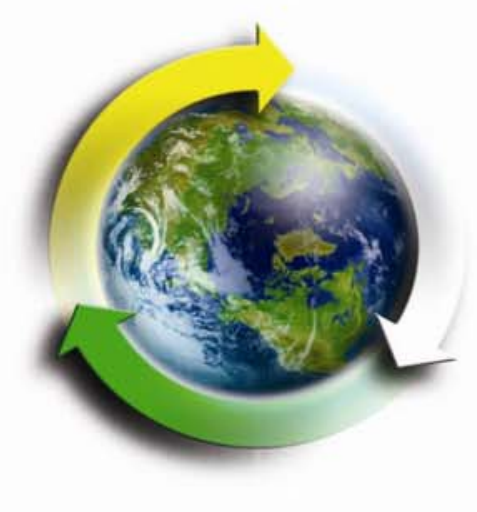

\title{
Initial Characterization
} and Performance Evaluation of a

Zirconium-Based Metallic Waste Form

Global Nuclear Energy Partnership

Prepared for

U.S. Department of Energy Waste Form Campaign

M.C. Kane

R.L. Sindelar

September, 2008

GNEP-WAST-WAST-TD-RP-2008-000299

SRNS-STI-2008-00013 


\section{DISCLAIMER}

This information was prepared as an account of work sponsored by an agency of the U.S. Government. Neither the U.S. Government nor any agency thereof, nor any of their employees, makes any warranty, expressed or implied, or assumes any legal liability or responsibility for the accuracy, completeness, or usefulness, of any information, apparatus, product, or process disclosed, or represents that its use would not infringe privately owned rights. References herein to any specific commercial product, process, or service by trade name, trade mark, manufacturer, or otherwise, does not necessarily constitute or imply its endorsement, recommendation, or favoring by the U.S. Government or any agency thereof. The views and opinions of authors expressed herein do not necessarily state or reflect those of the U.S. Government or any agency thereof. 
Initial Characterization and Performance Evaluation of a Zirconium-Based Metallic Waste Form

DOCUMENT : $\quad$ GNEP-WAST-WAST-TD-RP-2008-000299, SRNS-STI-2008-00013

TITLE: Initial Characterization and Performance Evaluation of a Zirconium-Based Metallic Waste Form

\section{APPROVALS}


Initial Characterization and Performance Evaluation of a Zirconium-Based Metallic Waste Form 


\section{SUMMARY}

A metallic waste form or alloy system for immobilization of Zircaloy cladding hulls, Undissolved Solids (UDS), Technicium (Tc) metal and Transition Metal Fission Products (TMFP) waste stream materials from separations processes for commercial spent nuclear fuel has been developed, and initial characterization of the phase assemblage and composition, and corrosion testing under aqueous conditions has been completed for the waste form with various levels of surrogate waste species. The waste stream materials are those from processes being developed as part of the Separations Campaign under the Department of Energy's (DOE's) Global Nuclear Energy Partnership (GNEP) program. The development of waste forms for these materials is under the Waste Form Campaign.

\section{Initial Characterization of the Zirconium-Based Waste Form}

The metallic waste form is a $\mathrm{Zr}-\mathrm{Cu}-\mathrm{Fe}$ alloy $(70 \mathrm{Zr}-20 \mathrm{Cu}-10 \mathrm{Fe}$ is the baseline alloy) that can incorporate waste species in a multi-phase alloy in a melt process at a relatively low temperature compared to the melting points of the individual waste species. Non-radioactive species of the designated GNEP waste streams were added from 10 to $50 \mathrm{wt} \%$ with the constituents of the baseline alloy in a melt at a process temperature of $1300^{\circ} \mathrm{C}$, and the resultant phases and preliminary specie partitioning were characterized. Up to approximately $30 \%$ of the UDS + TMFP surrogate species can be incorporated within approximately seven distinct phases in the resultant alloy; also, up to approximately $40 \%$ of rhenium, the Tc surrogate specie, can be incorporated within approximately four distinct phases in the resultant alloy.

\section{Initial Performance Testing of the Zirconium-Based Waste Form}

Electrochemical testing in $\mathrm{pH} \mathrm{2,} \mathrm{4,} \mathrm{and} 10$ water was performed for the baseline and for selected waste form alloys. The results from Linear Polarization Rate tests showed low corrosion rates to be at or less than $55 \mu \mathrm{m} /$ year for the surrogate waste form alloys tested at room temperature at these conditions. Additional work to further characterize the specie partitioning to the phases, and to evaluate congruency of release is recommended to increase the readiness of this candidate alloy. Demonstration using actual waste stream materials would ultimately be required for full readiness of the waste form.

\section{Metallic Waste Form for the GNEP Waste Form Campaign}

An iron-based alloy that provides for minimum alloying materials additions to the waste stream materials (UDS, Tc, and TMFP) with the assumption of compaction of the cladding hulls is the leading metal waste form to be developed under the Waste Form Campaign under the GNEP program. This iron-based alloy, termed the Minimum Additives Waste Stabilization (MAWS) alloy system would provide significantly less volume of metallic waste to immobilize the UDS, Tc, and TMFP species. The zirconium-based alloy described in this present report provides an alternative to the MAWS alloy system for programmatic risk reduction in the Waste Form Campaign. 
Initial Characterization and Performance Evaluation of a Zirconium-Based Metallic Waste Form 


\section{CONTENTS}

SUMMARY V

ACRONYMS $\mathrm{X}$

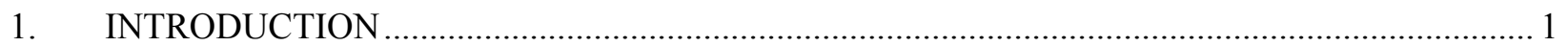

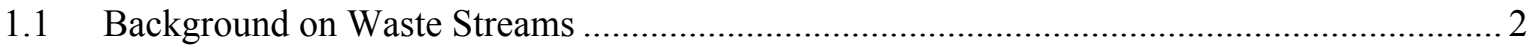

1.2 Summary of Previous Efforts in Waste Form Development..................................................... 3

2. DEVELOPMENT OF METALLIC WASTE FORM ALLOYS.................................................... 4

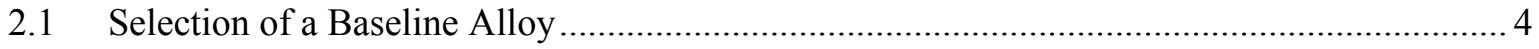

2.2 Fabrication of the Baseline Alloy ........................................................................... 7

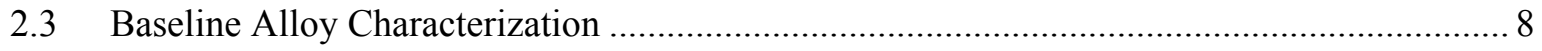

3. INTEGRATION OF WASTE STREAMS INTO A METALLIC WASTE FORM .......................9

3.1 Surrogate Waste Stream Composition ............................................................................ 9

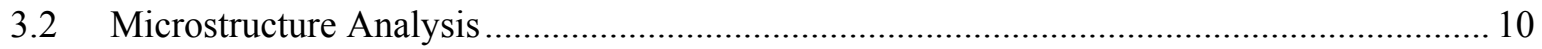

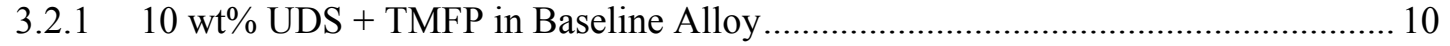

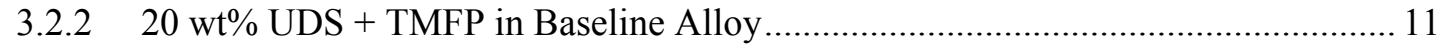

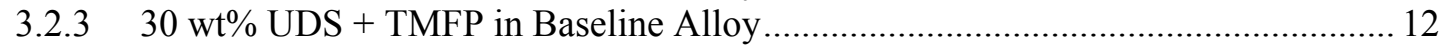

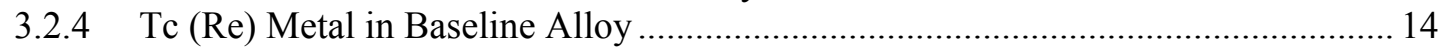

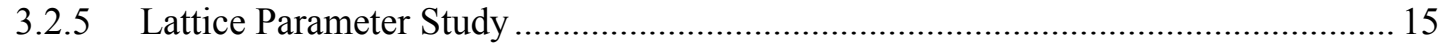

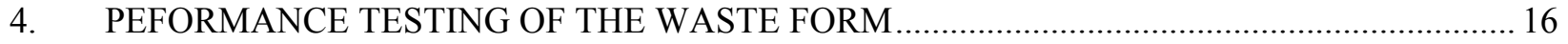

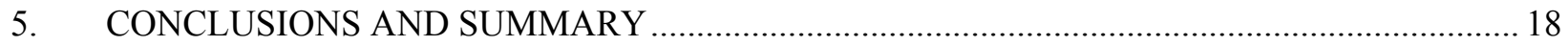

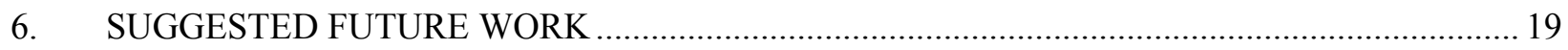

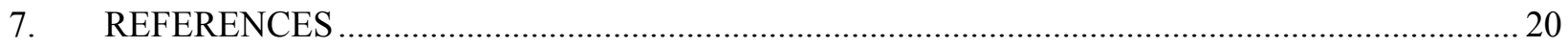

\section{FIGURES}

Figure 1. The UREX +1a fuel processing (left) and the Echem process (right) ...................................2

Figure 2. Zr-Fe Binary Phase Diagram with ANL Zr-8SS and SS-15Zr Alloys indicated [4] ................. 4

Figure 3. Representative Microstructures for SS-15Zr and Zr-8SS Metallic Wasteforms [4].................. 4

Figure 4. Zirconium-Copper-Iron Phase Diagram Isothermal at $1000{ }^{\circ} \mathrm{C}$ [12] ..................................... 5

Figure 5. Liquidus Projection for Zr-Cu-Fe Ternary Alloy System [13] .............................................. 6

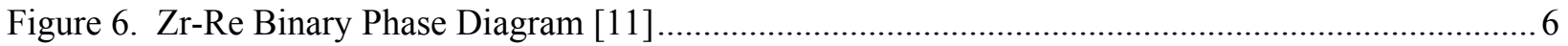

Figure 8. Arc melted baseline alloy (left) and furnace melted baseline alloy (right). Both alloys contain the same phase composition, but possess different microstructures. .............................. 8

Figure 9. SEM micrograph of the baseline alloy with four phases indicated .......................................... 8

Figure 10. XRD Data showing four phases for $70 \mathrm{Zr}-20 \mathrm{Cu}-10 \mathrm{Fe}$ (baseline alloy). Note the phase types and lattice parameters shown. 
Figure 11. Picture of the baseline alloy combined with waste stream surrogates after furnace melting. 10

Figure 12. Two SEM micrographs of $10 \mathrm{wt} \%$ loading of waste stream elements into the baseline alloy. The scale bars represent $20 \mu \mathrm{m}$ (left) and $200 \mu \mathrm{m}$ (right).

Figure 13. Two SEM micrographs of $20 \mathrm{wt} \%$ loading of waste stream elements into the baseline alloy. The scale bars represent $200 \mu \mathrm{m}$ (left) and $50 \mu \mathrm{m}$ (right). 12

Figure 14. Two SEM micrographs of $30 \mathrm{wt} \%$ loading of waste stream elements into the baseline alloy. The scale bars represent $200 \mu \mathrm{m}$ (left) and $50 \mu \mathrm{m}$ (right). 13

Figure 15. SEM micrographs of Re (surrogate for Tc) metal in the baseline alloy, $10-40 \mathrm{wt} \%$ loading. The scale bars all represent $50 \mu \mathrm{m}$. 15

Figure 16. Cyclic Polarization curves for selected waste form specimens at $\mathrm{pH}=2$ conditions. 17

Figure 17. Cyclic Polarization curves for selected waste form specimens at $\mathrm{pH}=4$ conditions.............. 17

Figure 18. Cyclic Polarization curves for selected waste form specimens at $\mathrm{pH}=10$ conditions. 18

\section{TABLES}

Table 1. Candidate alloy compositions.

Table 2. Projected solubilities and intermetallic formation of waste stream elements in baseline alloy compounds [6] 7

Table 3. Phase compositions identified by EDS in the baseline alloy ................................................. 8

Table 4. Estimated alloy compositions per ton of processed fuel [6] 10

Table 5. Composition of the waste stream elements (UDS + TMFP) used in these experiments, (wt\%)

Table 6. Phase compositions identified by EDS in the baseline alloy $+10 \mathrm{wt} \%$ UDS + TMFP $(\mathrm{wt} \%)$

Table 7. Phase compositions identified by EDS in the baseline alloy $+20 \mathrm{wt} \%$ UDS + TMFP $(\mathrm{wt} \%)$

Table 8. Phase compositions identified by EDS in the baseline alloy $+30 \mathrm{wt} \%$ UDS + TMFP $(\mathrm{wt} \%)$

Table 9. Maximum concentrations of waste stream components in various phases of the baseline alloy, in atomic \%.

Table 10. Phase compositions identified by EDS in the baseline alloy $+10 \mathrm{wt} \%$ Re, in $w \mathrm{t} \% \ldots \ldots \ldots \ldots \ldots . . . . . .14$

Table 11. Phase compositions identified by EDS in the baseline alloy $+20 \mathrm{wt} \% \mathrm{Re}$, in $\mathrm{wt} \%$................ 14

Table 12. Phase compositions identified by EDS in the baseline alloy $+30 \mathrm{wt} \% \mathrm{Re}$, in $\mathrm{wt} \% \ldots \ldots \ldots \ldots \ldots . . . . . .14$

Table 13. Phase compositions identified by EDS in the baseline alloy $+40 \mathrm{wt} \% \mathrm{Re}$, in $\mathrm{wt} \%$................ 14

Table 14. Phase types and lattice parameters for each phase identified by XRD in all alloy samples of baseline + waste stream elements. Question marks indicate that the lattice parameters could not be resolved with the instrument, but the phase was identified. 16

Table 15. Calculated corrosion rates for selected tested alloys 18 
Initial Characterization and Performance Evaluation of a Zirconium-Based Metallic Waste Form 


\section{ACRONYMS}

$\begin{array}{ll}\text { ABR } & \text { Advanced Breeder Reactor } \\ \text { DOE } & \text { United States Department of Energy } \\ \text { EBR II } & \text { Experimental Breeder Reactor II } \\ \text { Echem } & \text { Electrochemical processing also called pyrochemical processing } \\ \text { EDS } & \text { energy dispersive x-ray spectroscopy } \\ \text { FP } & \text { fission products } \\ \text { FPEX } & \text { fission product extraction } \\ \text { FR } & \text { fast reactor } \\ \text { GNEP } & \text { Global Nuclear Energy Partnership } \\ \text { GTCC } & \text { greater than Class C } \\ \text { HLW } & \text { high-level waste } \\ \text { IWMS } & \text { Integrated Waste Management Strategy } \\ \text { LLW } & \text { low level waste } \\ \text { LWR } & \text { light water reactor } \\ \text { MAWS } & \text { Minimum Additives Waste Stabilization alloy } \\ \text { MTHM } & \text { metric tons of heavy metal } \\ \text { MTIHM } & \text { metric tons of initial heavy metal (fissile metal prior to irradiation) } \\ \text { MWF } & \text { metallic waste form } \\ \text { SEM } & \text { scanning electron microscopy } \\ \text { SNF } & \text { spent nuclear fuel } \\ \text { SRNL } & \text { Savannah River National Laboratory } \\ \text { SS } & \text { stainless steel } \\ \text { TALSPEAK } & \text { Trivalent Actinide Lanthanide Separations by Phosphorus-reagent Extraction } \\ & \text { from Aqueous Complexes } \\ \text { TMFP } & \text { transition metal fission products } \\ \text { TRU } & \text { transuranic } \\ \text { TRUEX } & \text { transuranic extraction } \\ \text { UDS } & \text { undissolved solids } \\ \text { UREX } & \text { uranium extraction (an aqueous separations process or in the case of variations } \\ \text { UREX+1a } & \text { a family of aqueous separations processes } \\ \text { WFC } & \text { Waste Form Campaign } \\ \text { XRD } & \text { x-ray diffraction } \\ & \end{array}$


Initial Characterization and Performance Evaluation of a Zirconium-Based Metallic Waste Form 



\section{WASTE FORM CAMPAIGN INITIAL CHARACTERIZATION AND PERFORMANCE EVALUATION OF A ZIRCONIUM-BASED METALLIC WASTE FORM}

\section{INTRODUCTION}

The major goal of the United States Department of Energy Global Nuclear Energy Partnership (GNEP) program is to develop technology to support the global expansion of abundant and clean nuclear energy while reducing the risk of nuclear proliferation [1]. Spent nuclear fuel from commercial light-water power reactors would be processed to recycle usable materials while destroying long-lived radioactive elements in an Advanced Breeder Reactor (ABR). A nuclear fuel recycling center would separate spent nuclear fuel into reusable and waste components and then manufacture new nuclear fast reactor fuel.

Radioactive waste streams would be destined for safe permanent disposal as a class of low-level waste (LLW) or as a repository waste. The GNEP Integrated Waste Management Strategy (IWMS) [2, 3] describes the baseline disposition paths for LLW and high level radioactive waste streams from both the aqueous Uranium Extraction (UREX) processes and the electrochemical partitioning (Echem) processes. Several waste streams from the UREX and Echem processes are envisioned to be melted into a metallic waste form for repository disposal $[2,3]$.

Specifically, the GNEP IWMS Waste Treatment Baseline Study report [3] suggests a metallic waste form (MWF) as the baseline to be used for immobilization of undissolved solids (UDS), Tc metal, and possibly transition metal fission products (TMFP) from the TRUEX raffinate from aqueous processing. The report also suggested that although the $\mathrm{Zr}$-cladding hull waste was not expected to be part of most of the GNEP waste streams for repository disposal, it could be used in the waste forms, especially for UDS and Tc metal.

A Zr-based waste form (Zr-8SS) was previously developed by ANL in support of the treatment of Nabonded EBR-II fuel [4]. The GNEP report [3] highlighted key results of this work by recognizing that alpha-Fe, FeZr intermetallics, and $\mathrm{Zr}$ intermetallics could incorporate the waste species. The melt process temperature for $\mathrm{Zr}-\mathrm{SS}$ or SS-Zr waste forms is approximately $1600^{\circ} \mathrm{C}$.

Leveraging the work on Zr-SS waste forms, a low-melt-temperature Zr-based alloy system that would incorporate the UREX and Echem waste streams was investigated at SNRL in FY07 [5]. This present report describes the set of initial work in forwarding the development and characterization of a low-melttemperature alloy, $70 \mathrm{Zr}-20 \mathrm{Cu}-10 \mathrm{Fe}$, and its capacity to incorporate the Tc metal, UDS, and TMFP into a waste form that assumes cladding hulls as the primary feed to the waste form.

In mid-2008, the GNEP Waste Form Campaign (WFC) recognized that an Fe-based waste form could provide a cost-effective, minimum-volume waste form, termed the Minimum Additives Waste Stabilization (MAWS) alloy system, for UDS, Tc, and TMFP streams [6]. The planning assumption is that the cladding hulls would be compacted as a disposal form and may be used in a limited extent for $\mathrm{Zr}$ additions to the MAWS. The further development of the MAWS under the GNEP WFC is planned for FY09. The Zr-based waste form described in this present report would provide a back-up alternative to the MAWS alloy system. No further development of the Zr-based waste form beyond the work performed in FY08 and presented herein is planned. 


\subsection{Background on Waste Streams}

The waste streams destined for a metallic waste form (MWF) originate from either of two categories of processes. The UREX +1 a process and the Echem process (Figure 1) contain process steps that generate waste streams for the MWF. In addition, the zircaloy cladding hulls are considered to be available as a feed material for the MWF.
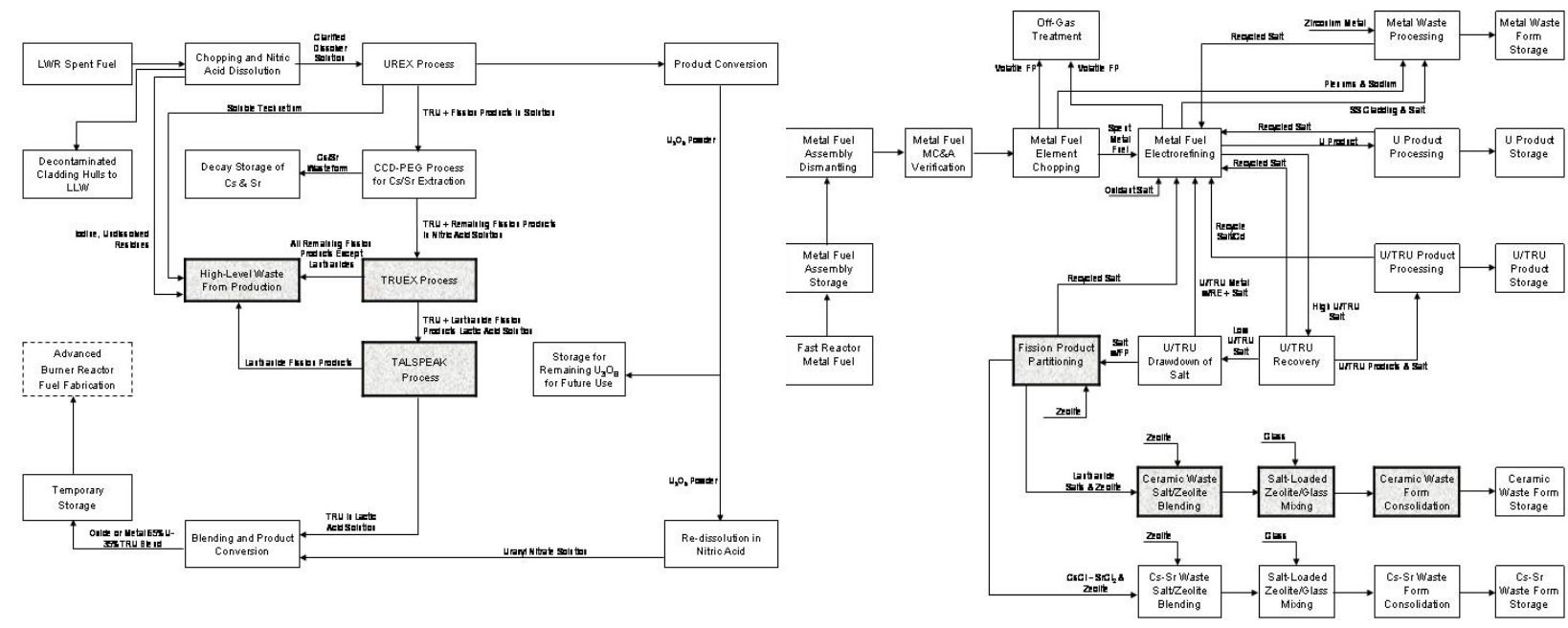

Figure 1. The UREX +1 a fuel processing (left) and the Echem process (right)

The undissolved solids (UDS) consist of the sludge recovered from the dissolver product after fuel dissolution. The UDS stream primarily contains the noble metal particles composed of transition metal fission products: $\mathrm{Zr}, \mathrm{Mo}, \mathrm{Pd}, \mathrm{Rh}, \mathrm{Ru}$ and Tc. Analysis by Adachi, et al. [7] showed that for power reactor fuel, about $70 \mathrm{wt} \%$ of the UDS were composed of Mo, Tc, Ru, Rh, and Pd with the remainder being chips of cladding (source of $\mathrm{Zr}$ ).

Only a small fraction of the total technetium (Tc) is left in the UDS. Primarily, Tc is separated in the UREX process (after acid dissolution) and captured on an anion exchange resin. It will be most likely converted to metallic Tc by either steam reduction or plated out on an iron substrate as a mixture of metallic Tc and oxide $\left(\mathrm{TcO}_{2}\right)$.

The TRUEX raffinate stream primarily contains the transition metal fission products (TMFP) of Zr, Mo, $\mathrm{Ru}, \mathrm{Rh}, \mathrm{Pd}, \mathrm{Ag}, \mathrm{Cd}, \mathrm{In}, \mathrm{Sn}, \mathrm{Sb}$, and Te in acetic acid and sulfate solution, which is the balance of the metal found in the TRUEX extraction step. This liquid stream, which contains added iron, must be treated to form either metallic or oxide phases to also be incorporated into a metallic waste form alloy.

Waste streams from the Echem processing steps are similar to those of the UREX process, except that all of the metallic Tc will be confined to an anode basket of the electrorefiner, which will also be considered waste. The basket is constructed mostly of stainless steel.

Unclean hulls contain small quantities of fission products [3]: $\mathrm{Mo}, \mathrm{Nb}, \mathrm{Pd}, \mathrm{Rh}, \mathrm{Ru}, \mathrm{Tc}, \mathrm{Te}$, and residual pieces of Zr. Cleaning or decontamination of the Zircaloy cladding hulls using HF solutions is being tested [8], and decontamination factors were developed for various radioisotopes. The results strongly suggest, however, that $U$ impurities in the Zircaloy lead to: 1) a fission product content; and 2) TRU products that were produced via neutron capture in the bulk cladding as a result of reactor operation. The TRU isotope concentration in all experiments generally exceeded the Class C LLW criteria or Greater Than Class C (GTCC) by at least an order of magnitude. 


\subsection{Summary of Previous Efforts in Waste Form Development}

Argonne National Laboratory (ANL) had previously developed a stainless steel/zirconium baseline waste form alloy for immobilizing radioactive metal fuel component waste from the electrometallurgical treatment of spent EBR-II fuel [4]. The metal waste stream consists of leftover metallic materials that are electrochemically inert in the electrorefiner. These materials include cladding hulls from the spent fuel assemblies, noble metal fission products (e.g., $\mathrm{Ru}, \mathrm{Rh}, \mathrm{Pd}, \mathrm{Nb}, \mathrm{Mo}$, and $\mathrm{Tc}$ ), and, in some cases, zirconium metal from alloy nuclear fuels.

Two stainless steel-zirconium alloy compositions were evaluated as baseline waste form alloys [4]: (a) stainless steel with $15 \mathrm{wt} \%$ zirconium for stainless steel-clad fuels and (b) zirconium with $8 \mathrm{wt} \%$ stainless steel for Zircaloy-clad fuels. Both the SS-15Zr and Zr-8SS were shown to have multi-phase microstructures that aid in immobilizing the radionuclide species in the alloy melts. The approximate composition of these two alloy systems as represented by the compositions marked on the Zr-Fe phase diagram in Figure 4. Typical microstructures of these two alloys are shown in Figure 4. The noble transition metal fission products were incorporated in the FeZr intermetallics [4]; and Technetium (Tc) was incorporated into the solid solution ferrite or austenite phases in the stainless steel/zirconium alloy [9]. The Zr-SS waste form also exhibit high resistance to corrosion in simulated groundwater as determined by immersion, electrochemical, and vapor hydration tests [4].

In FY07, the Savannah River National Laboratory (SRNL) investigated several alloy options for a "cladding hull waste form." The approach was to start with a zirconium-iron alloy and to evaluate composition variants to improve the processing conditions [5]. Copper was a key alloying addition that would enable a low temperature eutectic of approximately $1000^{\circ} \mathrm{C}$ to be targeted in a melt process; the use of copper would facilitate a batch process in a melt crucible where a copper feed would melt first to enable the other species to go into solution. Alternatively, a master alloy at a eutectic composition would be needed to facilitate a melt process at the low melt temperature.

In FY08, SRNL selected a low-melt-temperature alloy for further development as a candidate baseline alloy for immobilization and disposal of the Tc, TMFP, and UDS waste from the UREX +1 a process.

The alloy is composed of $70 \mathrm{Zr}-20 \mathrm{Cu}-10 \mathrm{Fe}$. The expected process temperature is approximately $1000{ }^{\circ} \mathrm{C}$. The waste stream components were expected to be incorporated into the candidate alloys as either specific intermetallic phases or in a solid solution with one of the constituent alloy species: $\mathrm{Zr}, \mathrm{Fe}$, or $\mathrm{Cu}$. 


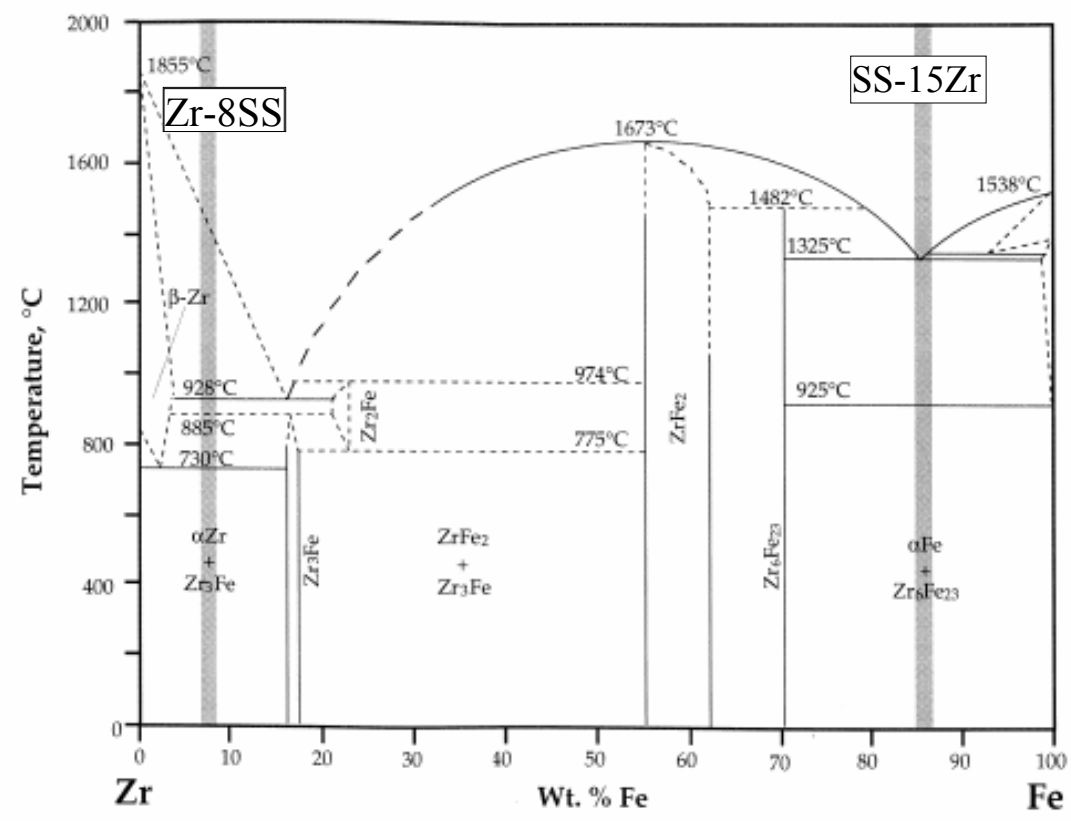

Figure 2. Zr-Fe Binary Phase Diagram with ANL Zr-8SS and SS-15Zr Alloys indicated [4]

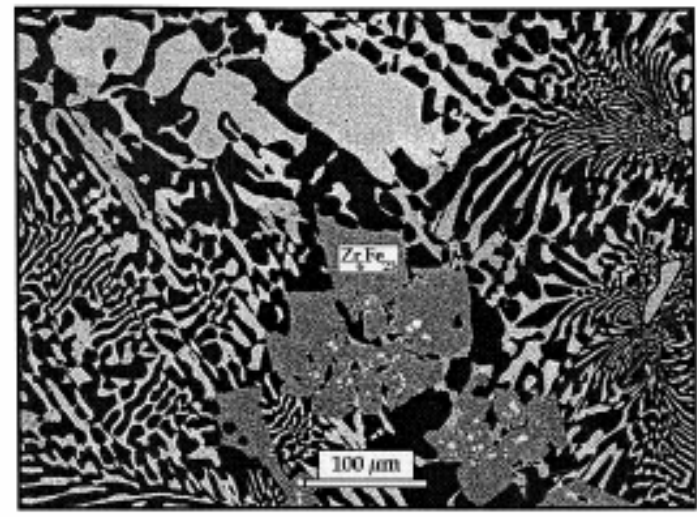

SS-15Zr Alloy

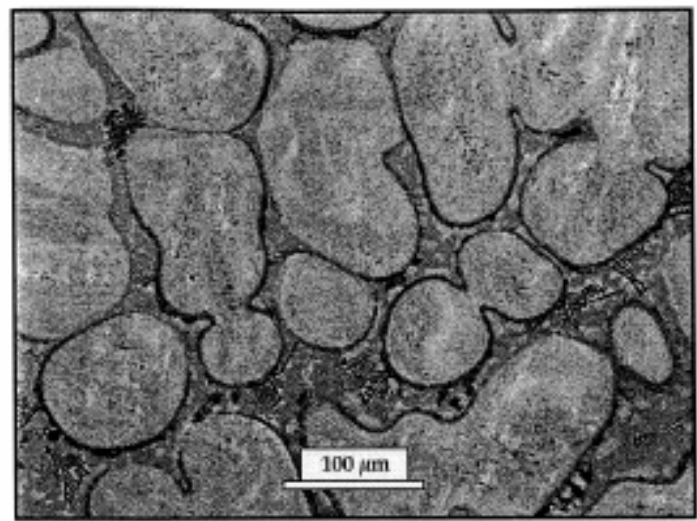

Zr-8SS Alloy

Figure 3. Representative Microstructures for SS-15Zr and Zr-8SS Metallic Wasteforms [4]

\section{DEVELOPMENT OF METALLIC WASTE FORM ALLOYS}

\subsection{Selection of a Baseline Alloy}

Initial experiments in FY07 [5] included the investigation of two different zirconium-based candidate alloys for Tc metal and UDS sequestration: $\mathrm{Zr}-\mathrm{Cu}$ and $\mathrm{Zr}-\mathrm{Cu}-\mathrm{Fe}$. Alloy compositions evaluated during this phase of the project are shown in Table 1. The $\mathrm{Zr}-\mathrm{Cu}$ system has been investigated based on previous work conducted by the CEA in 1981 that looked at the melting of Zr-cladding hulls as an alternative to mechanically compacting hulls during their reprocessing operations. The CEA examined the following alloys: $\mathrm{Zr}-\mathrm{Cu}, \mathrm{Zr}-\mathrm{Fe}$, and $\mathrm{Zr}-\mathrm{Ni}$ [10]. Their findings indicated that the $\mathrm{Zr}-\mathrm{Cu}$ alloy system afforded the best opportunity to operate a process at or below $1250^{\circ} \mathrm{C}$. SRNL conducted preliminary melting and characterization studies of a waste form based on a $\mathrm{Zr}-\mathrm{Cu}$ binary alloy [5]. In addition to the binary $\mathrm{Zr}$ $\mathrm{Cu}$ system, an evaluation of a ternary $\mathrm{Zr}-\mathrm{Cu}-\mathrm{Fe}$ alloy was performed [5]. The isothermal ternary phase 
diagram and liquidus projection (Figures 4 and 5) indicate that there is a wide range of compositions that can achieve melting; thus, the composition of the baseline alloy can be easily modified according to process conditions and the melt temperature can be lowered even further than the original target of 1000 ${ }^{\circ} \mathrm{C}$.

Examination of the $\mathrm{Zr}-\mathrm{Fe}$ and $\mathrm{Zr}-\mathrm{Re}$ (Re as a Tc surrogate since there is no $\mathrm{Zr}$ - $\mathrm{Tc}$ diagram binary) phase diagrams (Figure 6 and Figure 7) has shown numerous Fe-Zr and Zr-Re intermetallic phases of differing stoichiometries. Noble metal fission products (UDS-type products) were observed to be partitioned within $\mathrm{Zr}-\mathrm{Fe}$ intermetallics [4]. Table 2 shows the projected solubilities and intermetallic formation of each of the waste stream elements with the Fe and $\mathrm{Zr}[6]$.

Table 1. Candidate alloy compositions.

\begin{tabular}{|r|c|c|}
\cline { 2 - 3 } \multicolumn{1}{c|}{} & $\begin{array}{c}\text { Zr-Cu alloy } \\
\text { wt. \% }\end{array}$ & $\begin{array}{c}\text { Zr-Cu-Fe } \\
\text { alloy wt. \% }\end{array}$ \\
\hline $\mathrm{Zr}$ & 79 & 70 \\
\hline $\mathrm{Cu}$ & 21 & 20 \\
\hline $\mathrm{Fe}$ & -- & 10 \\
\hline
\end{tabular}

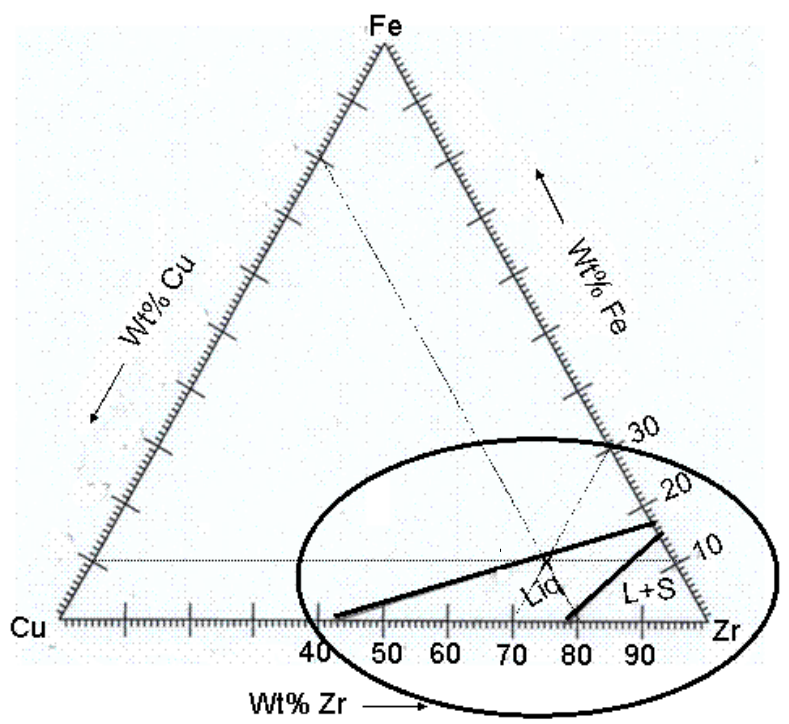

Figure 4. Zirconium-Copper-Iron Phase Diagram Isothermal at $1000^{\circ} \mathrm{C}[12]$ 


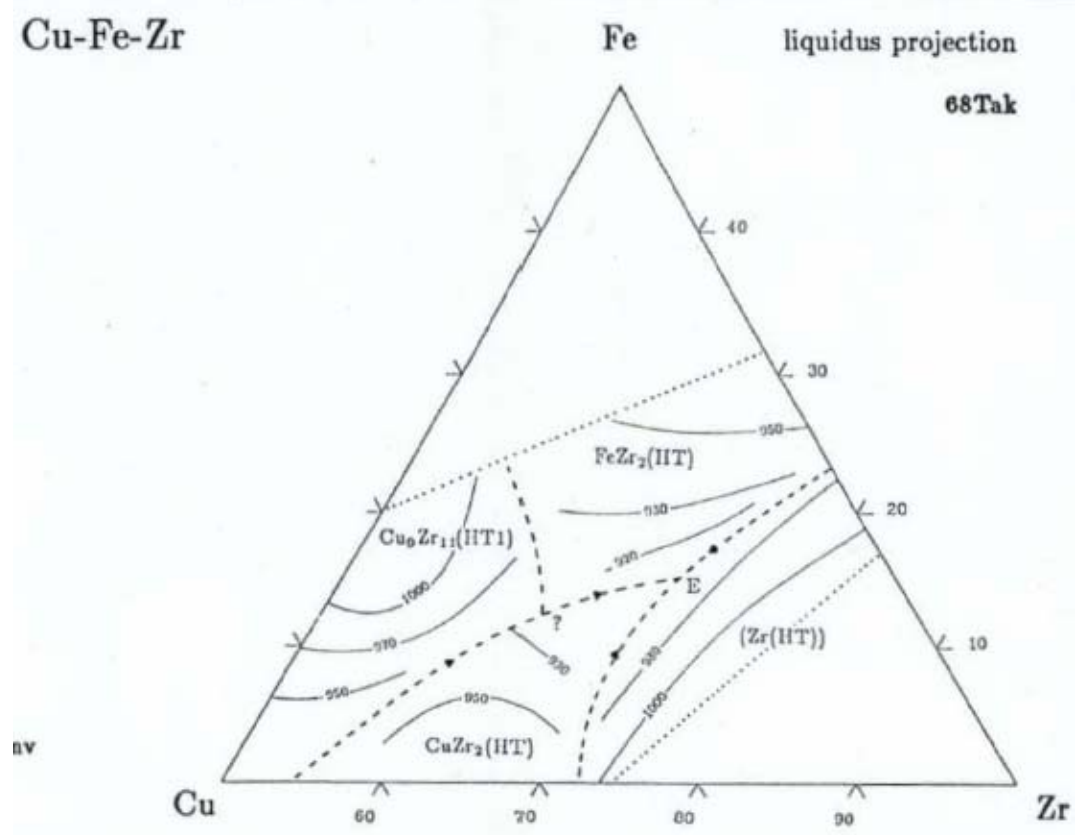

Figure 5. Liquidus Projection for Zr-Cu-Fe Ternary Alloy System [13]

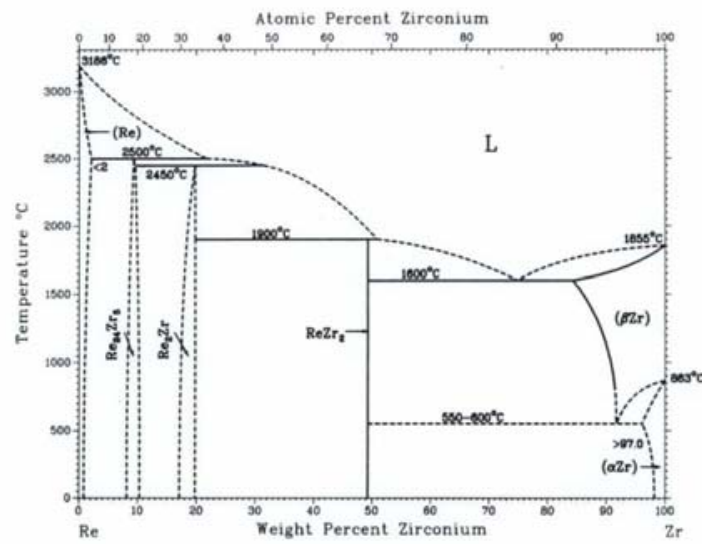

Figure 6. Zr-Re Binary Phase Diagram [11] 


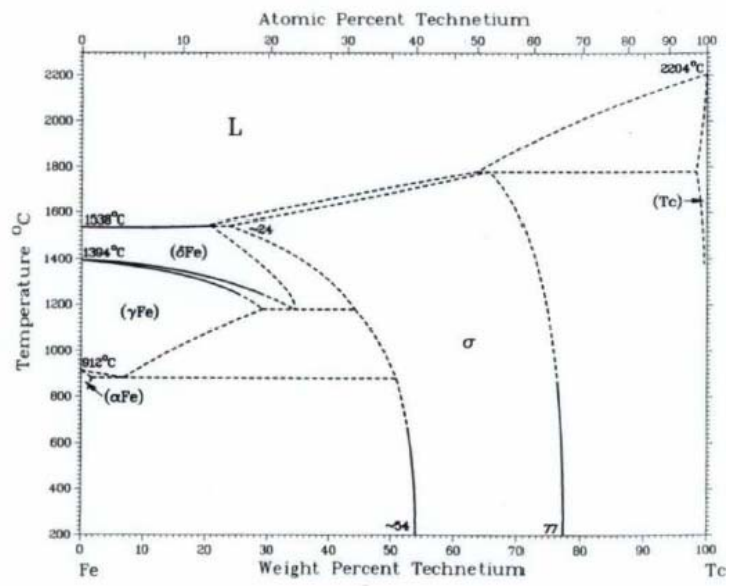

Figure 7. Fe-Tc Binary Phase Diagram [11]

Table 2. Projected solubilities and intermetallic formation of waste stream elements in baseline alloy compounds [6]

\begin{tabular}{|c|c|c|c|c|c|c|c|c|c|c|}
\hline & \multicolumn{10}{|c|}{ Maximum Solute Concentration, atomic $\%$} \\
\hline & $\mathrm{Mn}$ & $\mathrm{Fe}$ & $\mathrm{Cu}$ & $\mathrm{Zr}$ & Mo & Tc & $\mathrm{Ru}$ & $\mathrm{Rh}$ & $\mathrm{Pd}$ & $\operatorname{Re}$ \\
\hline $\mathrm{Fe}_{2} \mathrm{M}$ & & - & & $\mid \begin{array}{l}66- \\
73 \%\end{array}$ & $33.3 \%$ & & & & & \\
\hline FeM & $\begin{array}{l}0- \\
100 \% *\end{array}$ & - & $\begin{array}{l}45- \\
50 \%\end{array}$ & — & $\begin{array}{l}43- \\
57 \%\end{array}$ & $\begin{array}{l}15- \\
66 \%\end{array}$ & & $\begin{array}{l}0- \\
100 \% *\end{array}$ & $\begin{array}{l}0- \\
100 \% *\end{array}$ & \\
\hline $\mathrm{ZrM}_{2}$ & $\begin{array}{l}60- \\
80 \%\end{array}$ & $\begin{array}{l}66- \\
73 \%\end{array}$ & & - & $\begin{array}{l}60- \\
67 \%\end{array}$ & No & & & & $\begin{array}{l}66- \\
70 \%\end{array}$ \\
\hline ZrM & & - & $50 \%$ & - & & No & $50 \%$ & & & \\
\hline $\mathrm{Zr}_{2} \mathrm{M}$ & & $32 \%$ & $33 \%$ & |- & & No & & $33 \%$ & $34 \%$ & $33 \%$ \\
\hline
\end{tabular}

\subsection{Fabrication of the Baseline Alloy}

Initial experiments utilized arc melting to fabricate the baseline alloy [5]. Production of the MWF using resistance or induction furnace technology was envisioned for the process, and a furnace treatment used in this present work. Figure 8 shows the difference in microstructure achieved between non-equilibrium arc melting and furnace melting. A well-defined grain structure developed during the furnace cool cycle compared to the dendritic structure of the arc melt process.

Several melts of the baseline alloy, $70 \mathrm{Zr}-20 \mathrm{Cu}-10 \mathrm{Fe}$, in various crucibles were first heated to $1300^{\circ} \mathrm{C}$ to test for crucible wetting and melt temperature. Alumina crucibles were selected for further melting experiments. 


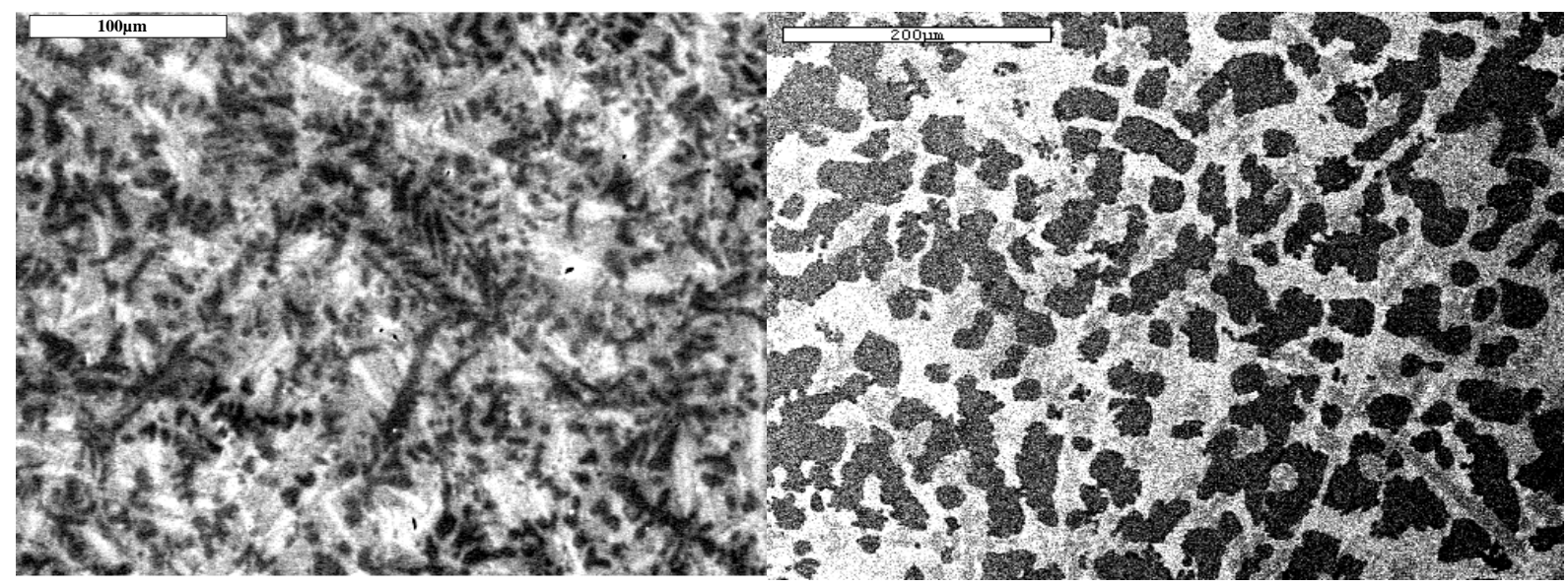

Figure 8. Arc melted baseline alloy (left) and furnace melted baseline alloy (right). Both alloys contain the same phase composition, but possess different microstructures.

\subsection{Baseline Alloy Characterization}

The baseline alloy was characterized by wide-angle $\mathrm{x}$-ray diffraction (XRD) and also energy dispersive $\mathrm{x}$ ray spectroscopy (EDS) by way of scanning electron microscopy (SEM). The SEM micrograph (Figure 9) of the baseline alloy identifies the four phases also identified by XRD. The EDS results (in wt\%) are shown in Table 3.

Table 3. Phase compositions identified by EDS in the baseline alloy

\begin{tabular}{|c|c|c|c|c|}
\hline & Overall & Phase 1 & Phase 2 & Phase 3 \\
\hline $\mathbf{Z r}$ & 70 & 77.4 & 78.37 & 63.55 \\
\hline $\mathbf{C u}$ & 20 & 13.2 & 10.48 & 24.99 \\
\hline $\mathbf{F e}$ & 10 & 9.36 & 11.15 & 11.46 \\
\hline
\end{tabular}

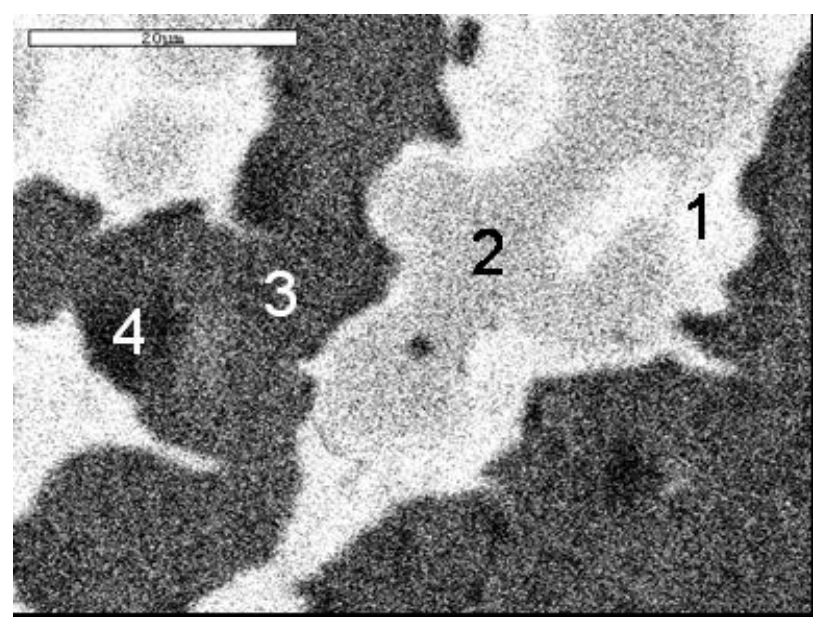

Figure 9. SEM micrograph of the baseline alloy with four phases indicated 


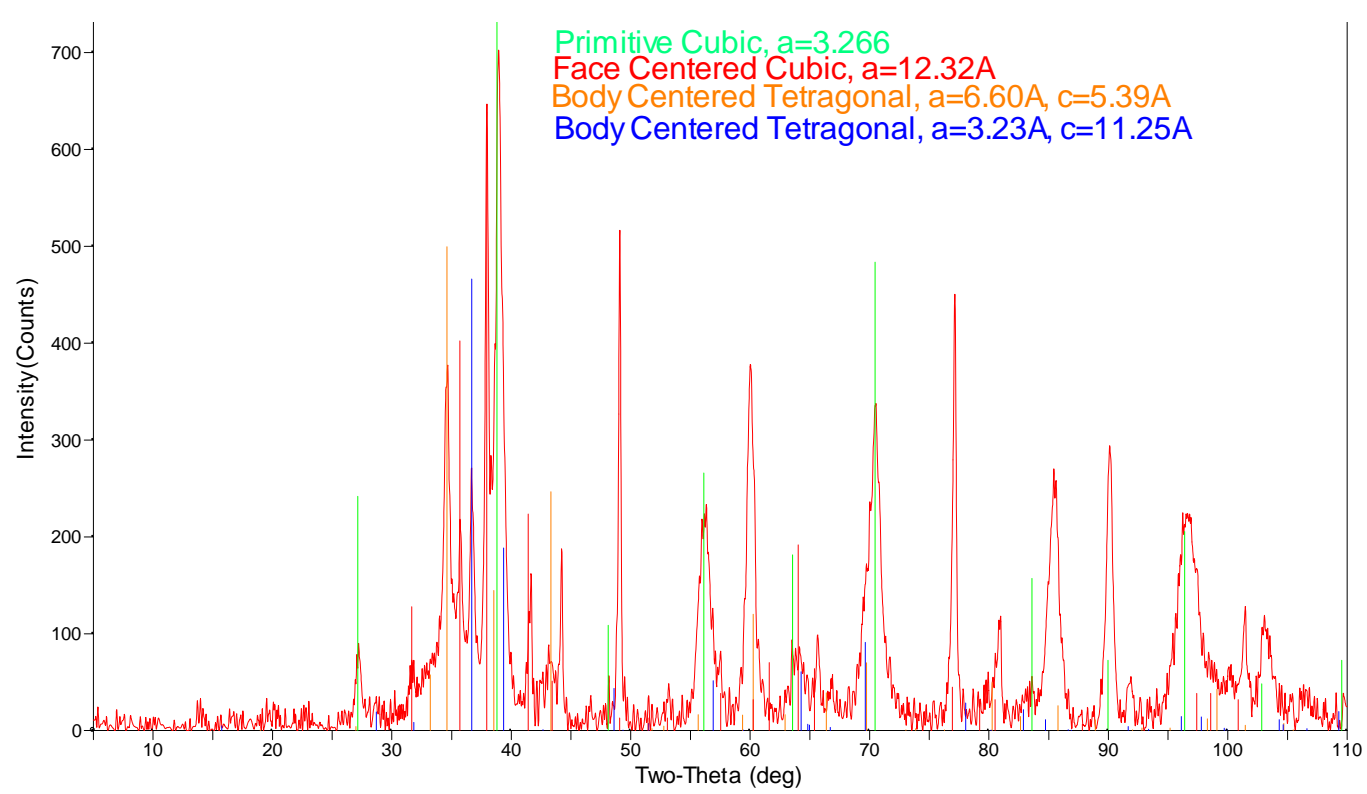

Figure 10. XRD Data showing four phases for $70 \mathrm{Zr}-20 \mathrm{Cu}-10 \mathrm{Fe}$ (baseline alloy). Note the phase types and lattice parameters shown.

\section{INTEGRATION OF WASTE STREAMS INTO A METALLIC WASTE FORM}

\subsection{Surrogate Waste Stream Composition}

Surrogate waste stream elements were furnace melted in alumina crucibles with the baseline alloy. The calculation of the composition of the waste stream surrogate elements was based on estimations from measurement of $51 \mathrm{GWd} / \mathrm{MTHM}$ aged 20 years and assumed separation efficiencies, shown in Table 4 [6].

For the $70 \mathrm{Zr}-20 \mathrm{Cu}-10 \mathrm{Fe}$ baseline alloy investigated in this present study, it was assumed that the $\mathrm{Fe}$ would be from the source of Fe in the waste stream. Additionally, the source of Ru and Pd metals in these experiments is a $10 \mathrm{wt} \% \mathrm{Pd}$ foil, which holds the ratio of $\mathrm{Pd}$ to $\mathrm{Ru}$ at 1:10. The actual composition of the waste stream elements found in the UDS and TMFP waste streams added to the baseline alloy in these experiments is shown in Table 5 .

The following sections detail the microstructural analysis of the resulting intermetallic formation from the addition of these surrogate waste stream elements by microscopy, energy dispersive x-ray spectroscopy (EDS) and also wide-angle $\mathrm{x}$-ray diffraction (XRD). 


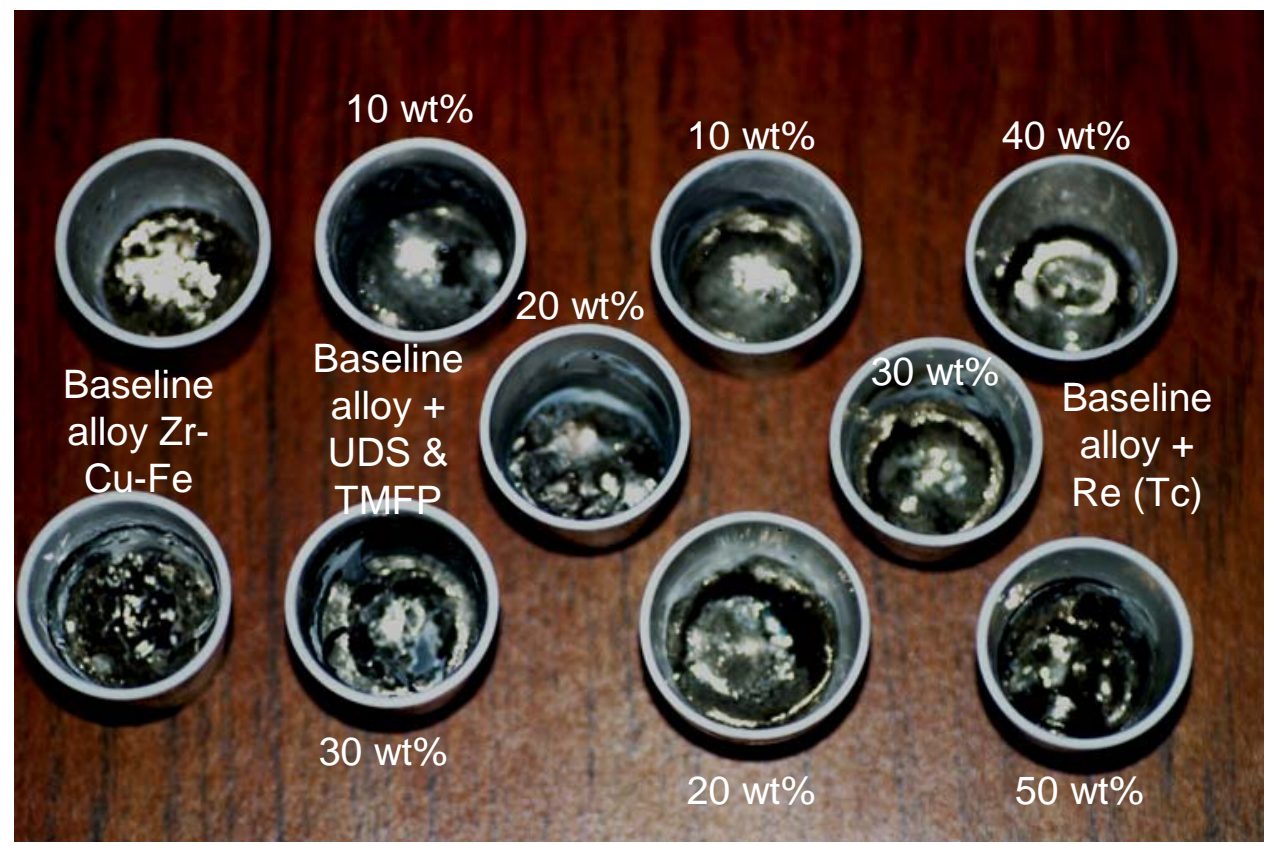

Figure 11. Picture of the baseline alloy combined with waste stream surrogates after furnace melting.

Table 4. Estimated alloy compositions per ton of processed fuel [6]

\begin{tabular}{|c|c|c|c|c|}
\hline & $\begin{array}{c}9.9 \mathrm{~kg} \text { UDS } \\
+15 \mathrm{~kg} \mathrm{Fe}\end{array}$ & $\begin{array}{c}9.9 \mathrm{~kg} \text { UDS + } \\
0.9 \mathrm{~kg} \mathrm{Tc}+17 \mathrm{~kg} \mathrm{Fe}\end{array}$ & $\begin{array}{c}9.0 \mathrm{~kg} \text { TMFP } \\
+15 \mathrm{~kg} \mathrm{Fe}\end{array}$ & $\begin{array}{c}\text { UDS + Tc + TMFP } \\
+32 \mathrm{~kg} \mathrm{Fe}\end{array}$ \\
\hline $\mathrm{Fe}$ & $60.30 \%$ & $61.27 \%$ & $62.41 \%$ & $61.80 \%$ \\
\hline $\mathrm{Zr}$ & $7.48 \%$ & $6.70 \%$ & $15.73 \%$ & $10.89 \%$ \\
\hline $\mathrm{Mo}$ & $19.09 \%$ & $17.12 \%$ & $1.49 \%$ & $9.86 \%$ \\
\hline $\mathrm{Tc}$ & $1.11 \%$ & $4.13 \%$ & - & $2.21 \%$ \\
\hline $\mathrm{Ru}$ & $6.59 \%$ & $5.91 \%$ & $7.70 \%$ & $6.74 \%$ \\
\hline $\mathrm{Rh}$ & $0.96 \%$ & $0.86 \%$ & $1.55 \%$ & $1.18 \%$ \\
\hline $\mathrm{Pd}$ & $2.75 \%$ & $2.47 \%$ & $6.95 \%$ & $4.55 \%$ \\
\hline $\mathrm{Te}$ & - & - & $2.45 \%$ & $1.46 \%$ \\
\hline
\end{tabular}

Table 5. Composition of the waste stream elements (UDS + TMFP) used in these experiments, (wt $\%)$

\begin{tabular}{|c|c|}
\hline Mo & $29.25 \%$ \\
\hline Tc (Re) & $1.57 \%$ \\
\hline Ru & $19.92 \%$ \\
\hline Rh & $44.34 \%$ \\
\hline Pd & $4.93 \%$ \\
\hline
\end{tabular}

\subsection{Microstructure Analysis}

\subsection{1 $10 \mathrm{wt} \%$ UDS + TMFP in Baseline Alloy}

The lowest loading of waste stream elements into the baseline alloy $(10 \mathrm{wt} \%)$ has an overall calculated composition of Zr63-Cu18-Fe9-Mo2.9-Rh4.4-Ru2-Pd0.5-Re0.2. The EDS technique identified four phases, which are the same basic phases that were identified in the baseline alloy (by XRD). This would 
indicate that the small loading of waste stream elements integrated completely into the baseline alloy intermetallics. The compositions of the four identified phases are shown in Table 6 . The area where the phase composition was measured can be seen in the SEM micrographs of Figure 12.

Table 6. Phase compositions identified by EDS in the baseline alloy $+10 \mathrm{wt} \%$ UDS + TMFP (wt $\%)$

\begin{tabular}{|c|c|c|c|c|c|}
\hline & Overall & Phase 1 & Phase 2 & Phase 3 & Phase 4 \\
\hline $\mathbf{Z r}$ & 63 & 63.47 & 78.18 & 60.85 & 57.67 \\
\hline $\mathbf{C u}$ & 18 & 19.95 & 9.09 & 20.44 & 18.67 \\
\hline $\mathbf{F e}$ & 9 & 9.5 & 10.57 & 9.41 & 7.18 \\
\hline $\mathbf{M o}$ & 2.9 & 4.57 & 2.26 & 4.29 & 5.05 \\
\hline $\mathbf{R h}$ & 4.4 & 0.95 & -- & -- & -- \\
\hline $\mathbf{R u}$ & 2 & 3.16 & -- & 1.05 & 6.84 \\
\hline $\mathbf{P d}$ & 0.5 & -- & 2.96 & 5.6 & 5.69 \\
\hline $\mathbf{T c} \mathbf{( R e )}$ & 0.2 & -- & -- & -- & -- \\
\hline
\end{tabular}
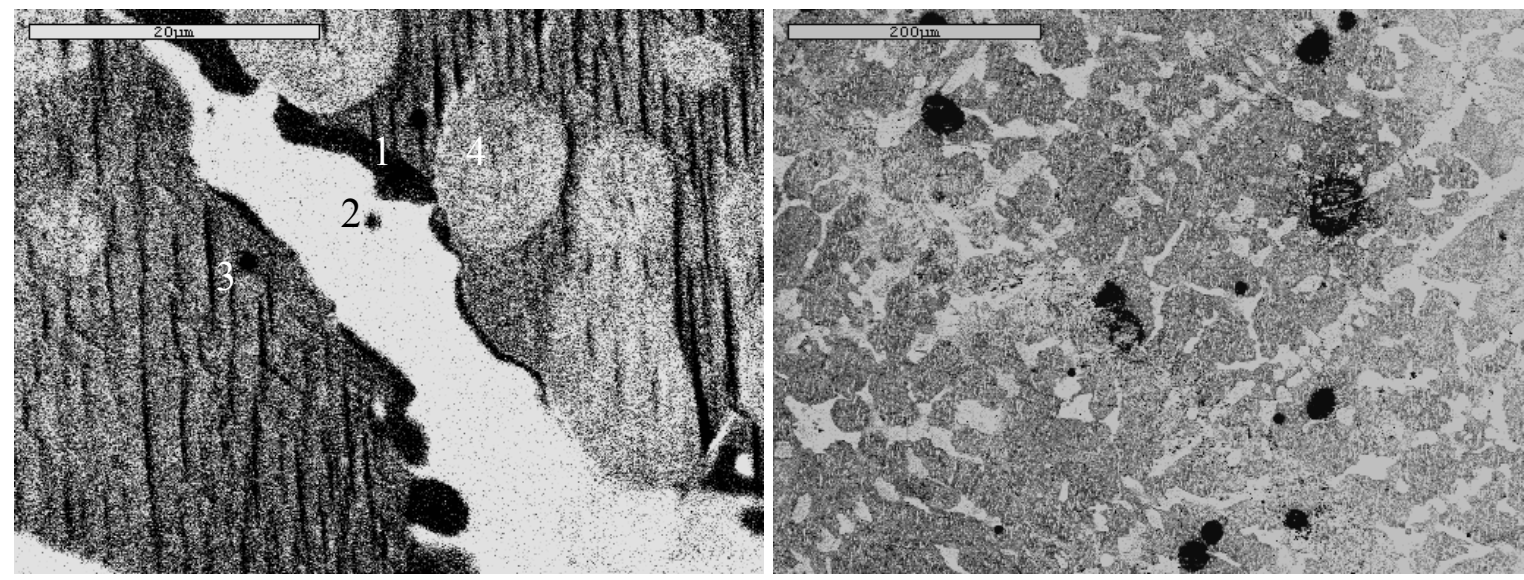

Figure 12. Two SEM micrographs of $10 \mathrm{wt} \%$ loading of waste stream elements into the baseline alloy. The scale bars represent $20 \mu \mathrm{m}$ (left) and $200 \mu \mathrm{m}$ (right).

\subsection{2 $20 \mathrm{wt} \%$ UDS + TMFP in Baseline Alloy}

The $20 \mathrm{wt} \%$ loading of UDS and TMFP waste stream elements has a calculated composition of Zr56Cu16-Fe8-Mo5.8-Rh8.9-Ru4-Pd1-Re0.3. The EDS technique identified seven different phases in this alloy (Table 7), yet XRD only found 4 phases with a few out of resolution. It is assumed that the four major phases identified by XRD are those intermetallics of the baseline alloy and a few other intermetallics (Cu-rich, see phases 1, 6, and 7) that formed to accommodate the Pd metal in particular. 
Table 7. Phase compositions identified by EDS in the baseline alloy $+20 \mathrm{wt} \%$ UDS + TMFP (wt $\%$ )

\begin{tabular}{|c|c|c|c|c|c|c|c|c|}
\hline & Overall & Phase 1 & Phase 2 & Phase 3 & Phase 4 & Phase 5 & Phase 6 & Phase 7 \\
\hline Zr & 56 & 48.25 & 38.27 & 40.24 & 42.67 & 54.01 & 57.32 & 33.26 \\
\hline $\mathbf{C u}$ & 16 & 32.24 & 3.84 & 5.17 & 8.17 & 10.37 & 18.72 & 59.07 \\
\hline Fe & 8 & 2.86 & 14.91 & 19.02 & 21.74 & 3.55 & 5.99 & 1.26 \\
\hline Mo & 5.8 & 1.78 & 36.81 & 31.57 & 23.04 & 4.45 & 3.37 & -- \\
\hline Rh & 8.9 & -- & -- & -- & -- & -- & -- & -- \\
\hline Ru & 4 & -- & 5.76 & 3.87 & 2.24 & 17.39 & 2.34 & -- \\
\hline Pd & 1 & 15.67 & 1.57 & 1.61 & 2.76 & 9.91 & 12.92 & 7.24 \\
\hline Tc (Re) & 0.3 & -- & -- & -- & -- & -- & -- & -- \\
\hline
\end{tabular}
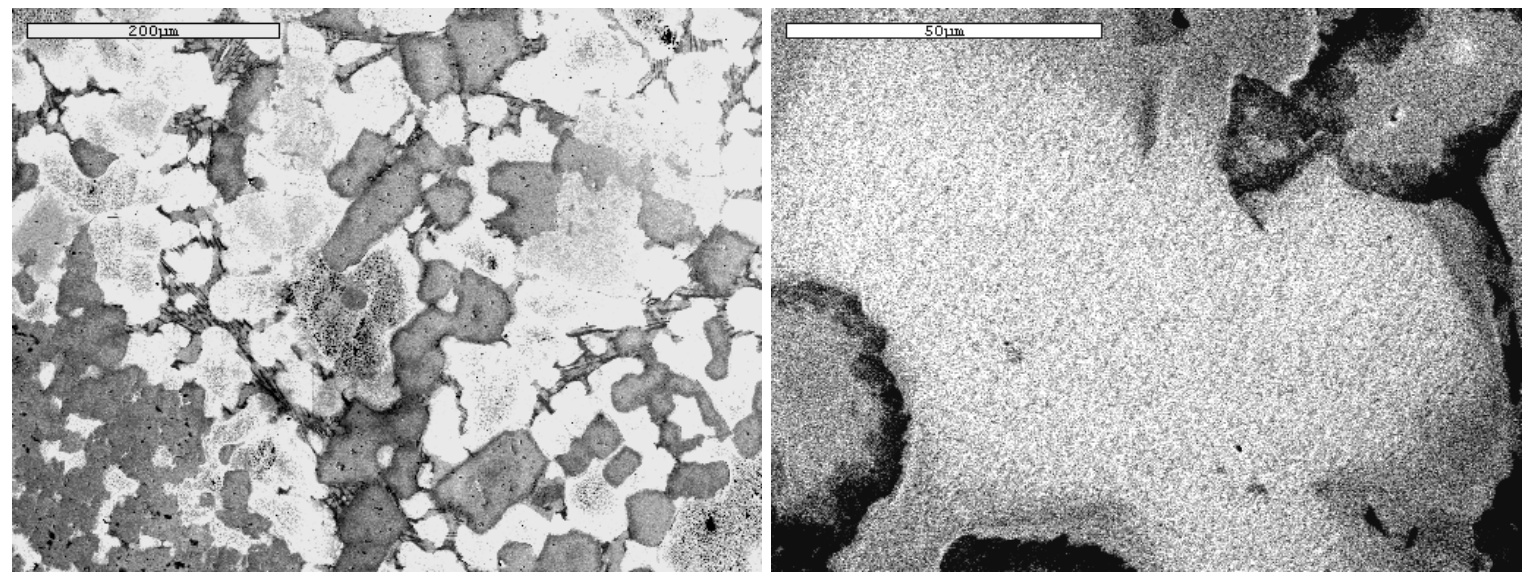

Figure 13. Two SEM micrographs of $20 \mathrm{wt} \%$ loading of waste stream elements into the baseline alloy. The scale bars represent $200 \mu \mathrm{m}$ (left) and $50 \mu \mathrm{m}$ (right).

\subsection{3 $30 \mathrm{wt} \%$ UDS + TMFP in Baseline Alloy}

The $30 \mathrm{wt} \%$ loading of UDS and TMFP waste stream elements has a calculated composition of Zr49Cu14-Fe7-Mo8.8-Rh13.3-Ru6-Pd1.5-Re0.5. The EDS technique identified three different phases in this alloy (Table 8) and XRD identified one additional eutectic $\mathrm{Cu}$-rich phase. The grain microstructure now looks quite different from that of the baseline alloy, although it seems like there are still four major phases in this alloy. XRD also found one additional phase, possibly $\mathrm{Cu}$-based, that was out of resolution of the instrument. These two latter phases (Cu-rich) are most likely the same as phases 1 and 7 of the $20 \mathrm{wt} \%$ loading alloy, which formed to accommodate the Pd, Ru and Rh metal.

It is interesting to note that the most $\mathrm{Cu}$-rich phase identified (phase 1, Table 8) held the most $\mathrm{Rh}, \mathrm{Ru}$ and Pd metal in the intermetallic phase. It had been previously suggested that these metals would only form intermetallics with $\mathrm{Zr}$ and $\mathrm{Fe}$ based on calculations of maximum concentration of waste metal components in predicted phases formed in the baseline alloy, taken from binary phase diagrams, shown in Table 9 [6]. 
Table 8. Phase compositions identified by EDS in the baseline alloy $+30 \mathrm{wt} \%$ UDS + TMFP (wt $\%$ )

\begin{tabular}{|c|c|c|c|c|}
\hline & Overall & Phase 1 & Phase 2 & Phase 3 \\
\hline $\mathbf{Z r}$ & 49 & 50.58 & 48.57 & 31.48 \\
\hline $\mathbf{C u}$ & 14 & 80.2 & 31.17 & 57.26 \\
\hline $\mathbf{F e}$ & 7 & 2.87 & 2.34 & 1.33 \\
\hline $\mathbf{M o}$ & 8.8 & 4.84 & 1.03 & -- \\
\hline $\mathbf{R h}$ & 13.3 & 3.21 & -- & -- \\
\hline $\mathbf{R u}$ & 6 & 14.99 & -- & -- \\
\hline $\mathbf{P d}$ & 1.5 & 17.32 & 17.64 & 9.9 \\
\hline Tc (Re) & 0.5 & -- & -- & -- \\
\hline
\end{tabular}

Table 9. Maximum concentrations of waste stream components in various phases of the baseline alloy, in atomic $\%$

\begin{tabular}{|c|c|c|c|c|c|c|c|c|c|c|}
\hline & \multicolumn{10}{|c|}{ Maximum Solute Concentration, atomic $\%$} \\
\hline & $\mathrm{Fe}$ & $\mathrm{Cr}$ & $\mathrm{Mn}$ & $\mathrm{Ni}$ & Mo & $\mathrm{Pd}$ & $\mathrm{Rh}$ & $\mathrm{Ru}$ & Tc & $\mathrm{Zr}$ \\
\hline$\gamma$-Fe & - & $11.9 \%$ & $100 \% *$ & $100 \%$ * & $1.7 \%$ & $100 \% *$ & $3 \%$ & $23 \%$ & $30 \%$ & $0.7 \%$ \\
\hline$\alpha-F e$ & - & $100 \%$ & $3 \%$ & $5.5 \%$ & $24 \%$ & $6.5 \%$ & $19 \%$ & $4 \%$ & $0 \%$ & $0.05 \%$ \\
\hline $\mathrm{Fe}_{2} \mathrm{M}$ & - & & & & $33.3 \%$ & & & & & $\begin{array}{c}66- \\
73 \%\end{array}$ \\
\hline FeM & - & $\begin{array}{c}45- \\
50 \%\end{array}$ & $\begin{array}{c}0- \\
100 \% *\end{array}$ & $\begin{array}{c}0- \\
100 \% *\end{array}$ & $\begin{array}{c}43- \\
57 \%\end{array}$ & $\begin{array}{c}0- \\
100 \% *\end{array}$ & $\begin{array}{c}0- \\
100 \% *\end{array}$ & & $\begin{array}{c}15- \\
66 \%\end{array}$ & - \\
\hline $\mathrm{ZrM}_{2}$ & $\begin{array}{c}66- \\
73 \%\end{array}$ & $\begin{array}{l}64- \\
69 \%\end{array}$ & $\begin{array}{c}60- \\
80 \%\end{array}$ & & $\begin{array}{l}60- \\
67 \%\end{array}$ & & & & No & - \\
\hline ZrM & - & & & & & & & $50 \%$ & No & 一 \\
\hline $\mathrm{Zr}_{2} \mathrm{M}$ & $32 \%$ & & & $33 \%$ & & $66 \%$ & $33 \%$ & & No & - \\
\hline
\end{tabular}
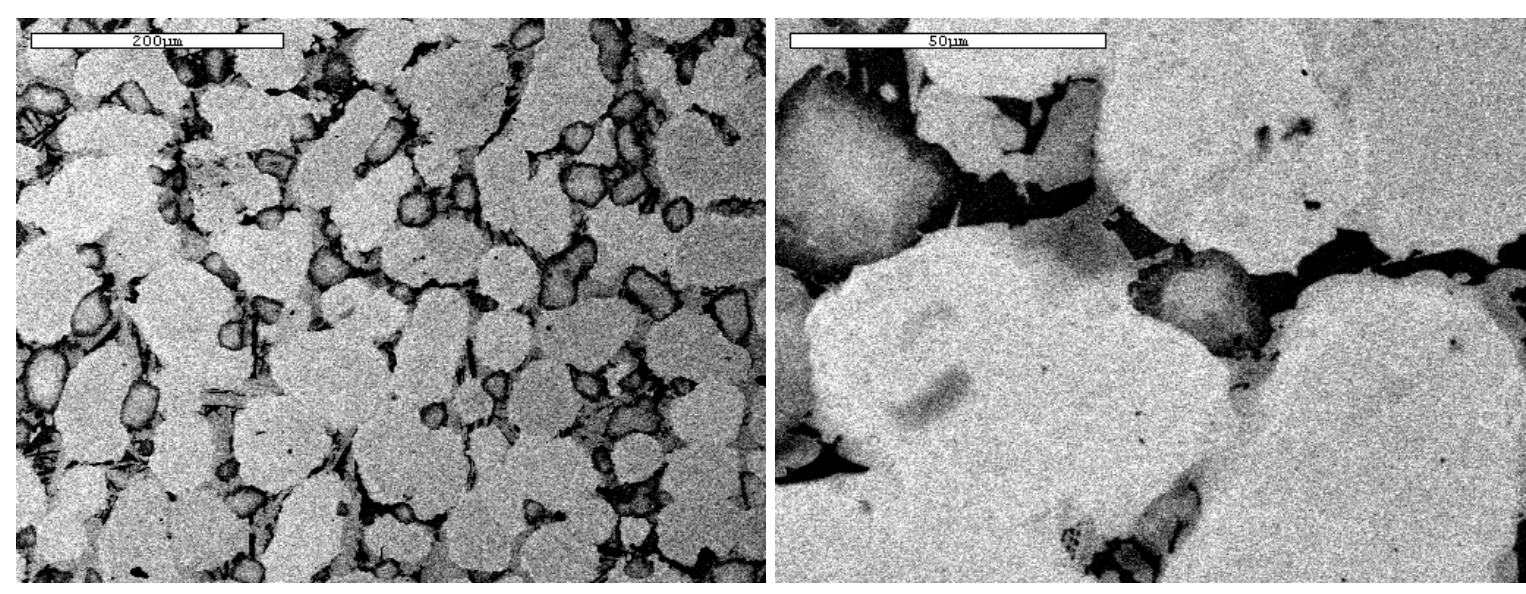

Figure 14. Two SEM micrographs of $30 \mathrm{wt} \%$ loading of waste stream elements into the baseline alloy. The scale bars represent $200 \mu \mathrm{m}$ (left) and $50 \mu \mathrm{m}$ (right). 


\subsubsection{Tc (Re) Metal in Baseline Alloy}

The addition of only Re metal (as a non-radioactive surrogate for Tc) to the baseline alloy was also investigated as it has been suggested that a waste form be developed solely for the disposal of Tc metal $[2,3]$. Re had fairly low solubility in the baseline intermetallics, and above $10 \mathrm{wt} \%$ loading, a $\mathrm{ZrRe}_{2}$ phase formed as it is shown to be only soluble in $\mathrm{Zr}$ metal. This contradicts the previous study on Tc ( $\operatorname{Re}$ thought to behave similarly) solubility on various phases of the baseline alloy based on binary phase diagrams (see Table 9). Re was found to be not soluble in any phase with a high $\mathrm{Fe}$ or $\mathrm{Cu}$ content. In general, the largest mass of Re sequestered to phases containing little or no $\mathrm{Fe}$ or $\mathrm{Cu}$ metals.

XRD identified the same four phases as the baseline alloy in each sample with the addition of the $\mathrm{ZrRe}_{2}$ phase(s) above $10 \mathrm{wt} \%$ Re. In the highest loading of Re in the baseline (40 wt \%), a primary Re phase formed as the solubility limit was reached (phase 6, Table 13). Due to high atomic number, the brightest spots on the SEM micrographs (Figure 15) are the phases with the highest content of Re metal.

Table 10. Phase compositions identified by EDS in the baseline alloy $+10 \mathrm{wt} \% \mathrm{Re}$, in wt $\%$

\begin{tabular}{|c|c|c|c|c|c|}
\hline & Overall & Phase 1 & Phase 2 & Phase 3 & Phase 4 \\
\hline $\mathbf{Z r}$ & 63 & 65.51 & 61.3 & 80.89 & 64.68 \\
\hline $\mathbf{C u}$ & 18 & 26.44 & 25.64 & 10.37 & 8.39 \\
\hline Fe & 9 & 10.36 & 9.72 & 12.12 & 6.61 \\
\hline Tc (Re) & 10 & -- & 3.35 & -- & 20.32 \\
\hline
\end{tabular}

Table 11. Phase compositions identified by EDS in the baseline alloy $+20 \mathrm{wt} \% \mathrm{Re}$, in wt $\%$

\begin{tabular}{|c|c|c|c|c|}
\hline & Overall & Phase 1 & Phase 2 & Phase 3 \\
\hline $\mathbf{Z r}$ & 56 & 65.51 & 69.9 & 66.27 \\
\hline $\mathbf{C u}$ & 16 & 25.12 & 20.46 & 7.85 \\
\hline $\mathbf{F e}$ & 8 & 10.4 & 8.71 & 7.3 \\
\hline Tc (Re) & 20 & -- & 0.93 & 18.58 \\
\hline
\end{tabular}

Table 12. Phase compositions identified by EDS in the baseline alloy $+30 \mathrm{wt} \% \mathrm{Re}$, in wt $\%$

\begin{tabular}{|c|c|c|c|c|c|c|}
\hline & Overall & Phase 1 & Phase 2 & Phase 3 & Phase 4 & Phase 5 \\
\hline Zr & 49 & 79.99 & 55.57 & 67.35 & 60.06 & 23.49 \\
\hline $\mathbf{C u}$ & 14 & 9.37 & 18.38 & 7.27 & 2.38 & -- \\
\hline Fe & 7 & 11.17 & 7.39 & 5.53 & 5.04 & 4.74 \\
\hline Tc (Re) & 30 & -- & 18.67 & 19.85 & 32.52 & 70.86 \\
\hline
\end{tabular}

Table 13. Phase compositions identified by EDS in the baseline alloy $+40 \mathrm{wt} \% \mathrm{Re}$, in $\mathrm{wt} \%$

\begin{tabular}{|c|c|c|c|c|c|c|c|}
\hline & Overall & Phase 1 & Phase 2 & Phase 3 & Phase 4 & Phase 5 & Phase 6 \\
\hline Zr & 42 & 77.19 & 57.41 & 65.2 & 22.42 & 20.71 & 2.2 \\
\hline $\mathrm{Cu}$ & 12 & 19.7 & 21.24 & 7.11 & 1.51 & -- & -- \\
\hline $\mathrm{Fe}$ & 6 & 2.5 & 7.32 & 3 & 4.91 & -- & -- \\
\hline Tc (Re) & 40 & -- & 14.03 & 21.7 & 71.16 & 78.49 & 97.77 \\
\hline
\end{tabular}




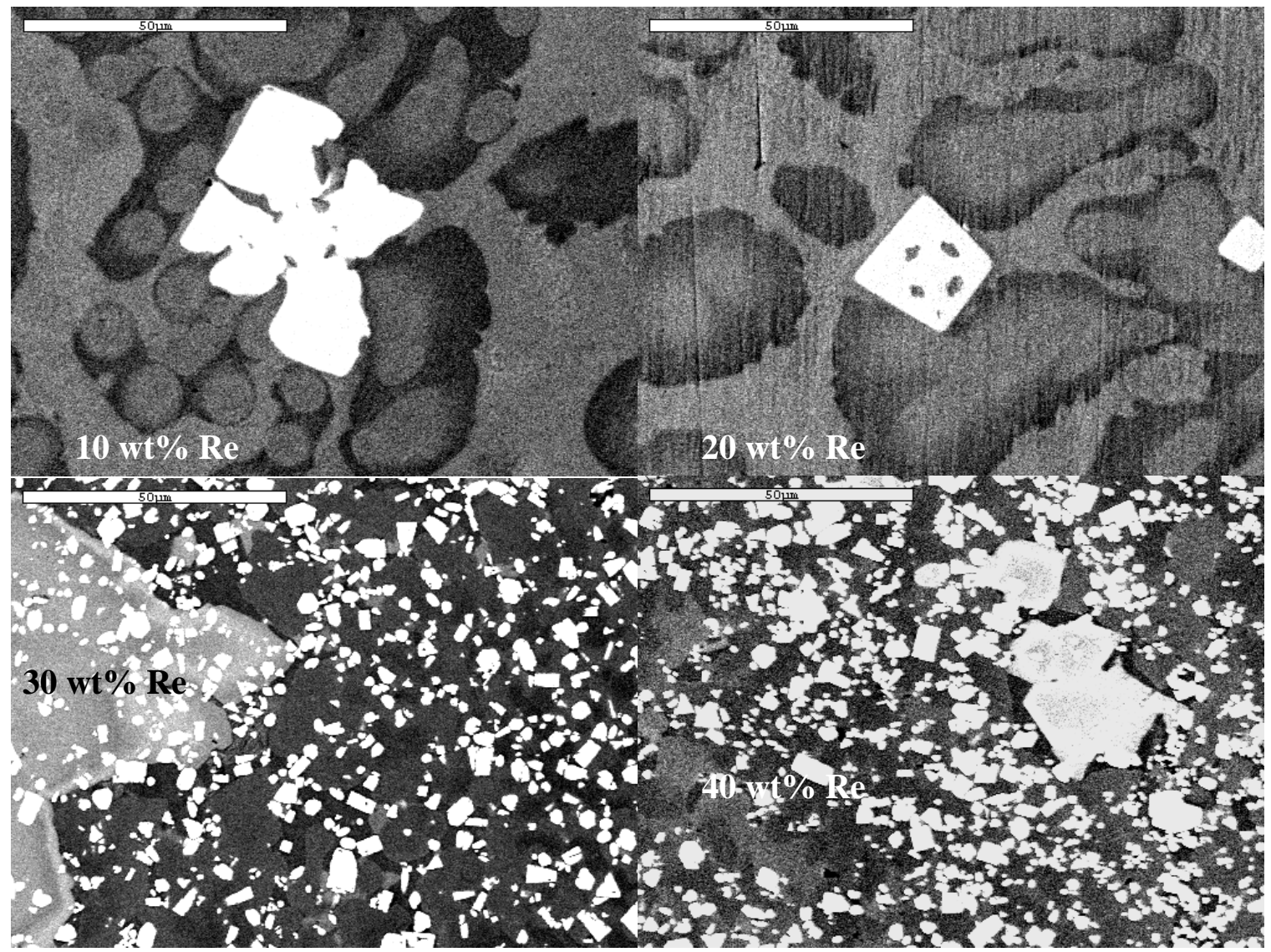

Figure 15. SEM micrographs of Re (surrogate for Tc) metal in the baseline alloy, 10-40 wt\% loading. The scale bars all represent $50 \mu \mathrm{m}$.

\subsubsection{Lattice Parameter Study}

The lattice parameters and phase types for each sample were identified with the XRD technique and are shown in Table 14. These results match reasonably well with the SEM/EDS technique, and reinforce the conclusions stated in previous sections. In general, the four phases (PC, FCC and two BCT) in the baseline alloy are found in most all of the samples with a few variations. The small changes in lattice parameter values from one sample to another can be attributed to the solubility of small amounts of the waste stream elements into the various intermetallics, thus changing the interatomic spacing due to a change in atomic radius.

The samples loaded with only Re metal show a marked decrease in the FCC lattice parameter from 10-40 wt\%. This may be attributed to $\mathrm{Zr}$ metal being pulled from the FCC phase into the $\mathrm{ZrRe}_{2}$ phase, due to the high solubility of $\mathrm{Re}$ in $\mathrm{Zr}$ and low solubility in the other baseline alloy metals $(\mathrm{Cu}, \mathrm{Fe})$. The XRD results also confirm the formation of a primary Re phase when $40 \mathrm{wt} \% \mathrm{Re}$ is loaded into the baseline alloy. 
Table 14. Phase types and lattice parameters for each phase identified by XRD in all alloy samples of baseline + waste stream elements. Question marks indicate that the lattice parameters could not be resolved with the instrument, but the phase was identified.

\begin{tabular}{|c|c|c|c|c|c|c|c|}
\hline & & Phase 1 & Phase 2 & Phase 3 & Phase 4 & Phase 5 & Phase 6 \\
\hline \multirow[t]{2}{*}{$\begin{array}{c}\text { Baseline } \\
\text { Alloy }\end{array}$} & $\begin{array}{l}\text { Phase } \\
\text { type }\end{array}$ & $\begin{array}{l}\text { FCC- } \\
\text { FeZr2 }\end{array}$ & $\begin{array}{l}\text { BCT- } \\
\text { FeZr2 }\end{array}$ & $\begin{array}{l}\text { PC- } \\
\text { CuZr }\end{array}$ & $\begin{array}{l}\text { BCT- } \\
\text { CuZr2 }\end{array}$ & & \\
\hline & \begin{tabular}{c|} 
Lattice \\
parameter
\end{tabular} & 12.35 & $6.57,5.36$ & 3.26 & $3.21,11.16$ & & \\
\hline \multirow[t]{2}{*}{\begin{tabular}{|c}
10 wt $\%$ FP + \\
UDS \\
\end{tabular}} & $\begin{array}{c}\text { Phase } \\
\text { type }\end{array}$ & $\begin{array}{l}\text { FCC- } \\
\text { FeZr2 }\end{array}$ & $\begin{array}{l}\text { BCT- } \\
\text { FeZr2 }\end{array}$ & $\begin{array}{l}\mathrm{PC}- \\
\mathrm{CuZr}\end{array}$ & $\begin{array}{l}\text { BCT- } \\
\text { CuZr2 }\end{array}$ & & \\
\hline & \begin{tabular}{|c|} 
Lattice \\
parameter
\end{tabular} & 12.32 & $6.60,5.39$ & 3.27 & $3.23,11.25$ & & \\
\hline \multirow[t]{2}{*}{$\begin{array}{c}20 \text { wt\% FP + } \\
\text { UDS }\end{array}$} & $\begin{array}{l}\text { Phase } \\
\text { type }\end{array}$ & $\begin{array}{l}\text { FCC- } \\
\text { FeZr2 }\end{array}$ & $\begin{array}{l}\text { BCT- } \\
\text { FeZr2 }\end{array}$ & $\begin{array}{l}\mathrm{PC}- \\
\mathrm{CuZr}\end{array}$ & $\begin{array}{l}\text { BCT- } \\
\text { CuZr2 }\end{array}$ & $\begin{array}{l}\text { Out of } \\
\text { res. }\end{array}$ & \\
\hline & \begin{tabular}{|c|} 
Lattice \\
parameter
\end{tabular} & 12.31 & $6.59,5.38$ & 3.27 & $3.23,11.21$ & & \\
\hline \multirow[t]{2}{*}{$\begin{array}{c}30 \text { wt\% FP + } \\
\text { UDS }\end{array}$} & $\begin{array}{l}\text { Phase } \\
\text { type }\end{array}$ & $\begin{array}{l}\text { FCC- } \\
\text { FeZr2 }\end{array}$ & $\begin{array}{l}\text { BCT- } \\
\text { FeZr2 }\end{array}$ & $\begin{array}{l}\text { PC- } \\
\text { CuZr }\end{array}$ & $\begin{array}{c}\text { BCT- } \\
\text { Cu2Zr?? }\end{array}$ & $\begin{array}{c}\text { Hex- } \mathrm{Cu} \\
\text { phase? }\end{array}$ & \\
\hline & \begin{tabular}{|c|} 
Lattice \\
parameter
\end{tabular} & 12.36 & $6.60,5.39$ & 3.28 & $3.25,4.94$ & $7.45,5.15$ & \\
\hline \multirow[t]{2}{*}{$10 \mathrm{wt} \% \mathrm{Re}$} & $\begin{array}{l}\text { Phase } \\
\text { type }\end{array}$ & $\begin{array}{l}\text { FCC- } \\
\text { FeZr2 }\end{array}$ & $\begin{array}{l}\text { BCT- } \\
\text { FeZr2 }\end{array}$ & $\begin{array}{l}\mathrm{PC}- \\
\mathrm{CuZr}\end{array}$ & $\begin{array}{l}\text { BCT- } \\
\text { CuZr2 }\end{array}$ & ZrRe2 & \\
\hline & \begin{tabular}{|c|} 
Lattice \\
parameter
\end{tabular} & 12.34 & $6.56,5.36$ & 3.26 & $3.23,11.21$ & $5.24,8.57$ & \\
\hline \multirow[t]{2}{*}{20 wt $\%$ Re } & $\begin{array}{c}\text { Phase } \\
\text { type }\end{array}$ & $\begin{array}{l}\text { FCC- } \\
\text { FeZr2 }\end{array}$ & $\begin{array}{l}\text { BCT- } \\
\text { FeZr2 }\end{array}$ & $\begin{array}{l}\text { PC- } \\
\text { CuZr }\end{array}$ & $\begin{array}{l}\text { BCT- } \\
\text { CuZr2 }\end{array}$ & ZrRe2 & \\
\hline & \begin{tabular}{c|} 
Lattice \\
parameter
\end{tabular} & 12.29 & $6.55,5.35$ & 3.25 & $3.21,11.17$ & $? ?$ & \\
\hline \multirow[t]{2}{*}{$30 \mathrm{wt} \% \mathrm{Re}$} & $\begin{array}{l}\text { Phase } \\
\text { type }\end{array}$ & $\begin{array}{l}\text { FCC- } \\
\text { FeZr2 }\end{array}$ & $\begin{array}{l}\text { BCT- } \\
\text { FeZr2 }\end{array}$ & $\begin{array}{l}\mathrm{PC}- \\
\mathrm{CuZr}\end{array}$ & $\begin{array}{l}\text { BCT- } \\
\text { CuZr2 }\end{array}$ & ZrRe2 & \\
\hline & \begin{tabular}{|c|} 
Lattice \\
parameter
\end{tabular} & 12.34 & $6.58,5.37$ & 3.25 & $3.23,11.21$ & $5.25,8.57$ & \\
\hline \multirow[t]{2}{*}{$40 \mathrm{wt} \% \mathrm{Re}$} & $\begin{array}{c}\text { Phase } \\
\text { type }\end{array}$ & $\begin{array}{l}\text { FCC- } \\
\text { FeZr2 }\end{array}$ & $\begin{array}{l}\text { BCT- } \\
\text { FeZr2 }\end{array}$ & $\begin{array}{l}\text { PC- } \\
\text { CuZr }\end{array}$ & $\begin{array}{l}\text { BCT- } \\
\text { CuZr2 }\end{array}$ & ZrRe2 & $\mathrm{Re}$ \\
\hline & \begin{tabular}{|c|} 
Lattice \\
parameter
\end{tabular} & 12.31 & ?? & 3.26 & $3.23,11.23$ & $5.25,8.58$ & $2.76,4.46$ \\
\hline
\end{tabular}

\section{PEFORMANCE TESTING OF THE WASTE FORM}

The waste forms investigated in this study were tested in $\mathrm{pH}$-adjusted solutions in order to determine the corrosion resistance of each alloy using a simple aqueous solution for a low-to-high $\mathrm{pH}$ repository environment. Cyclic polarization tests were used to determine the ability of the alloy to form a passivating layer on the surface, and linear polarization tests were used to determine the corrosion rate. Electrochemical tests were performed at room temperature in $\mathrm{pH} \mathrm{2,4}$ and 10 solutions adjusted with sodium hydroxide or nitric acid.

The cyclic polarization curves (Figures 16-18) show that the baseline alloy forms a complete passivation layer against corrosion. At pH 2 and 4, the alloy samples tested were all similar in response and it can be assumed that a similar passivating layer is formed on these alloys as well. However, for the tests run at $\mathrm{pH} 10$, the baseline alloy was not as stable and the alloys loaded with waste stream elements. 


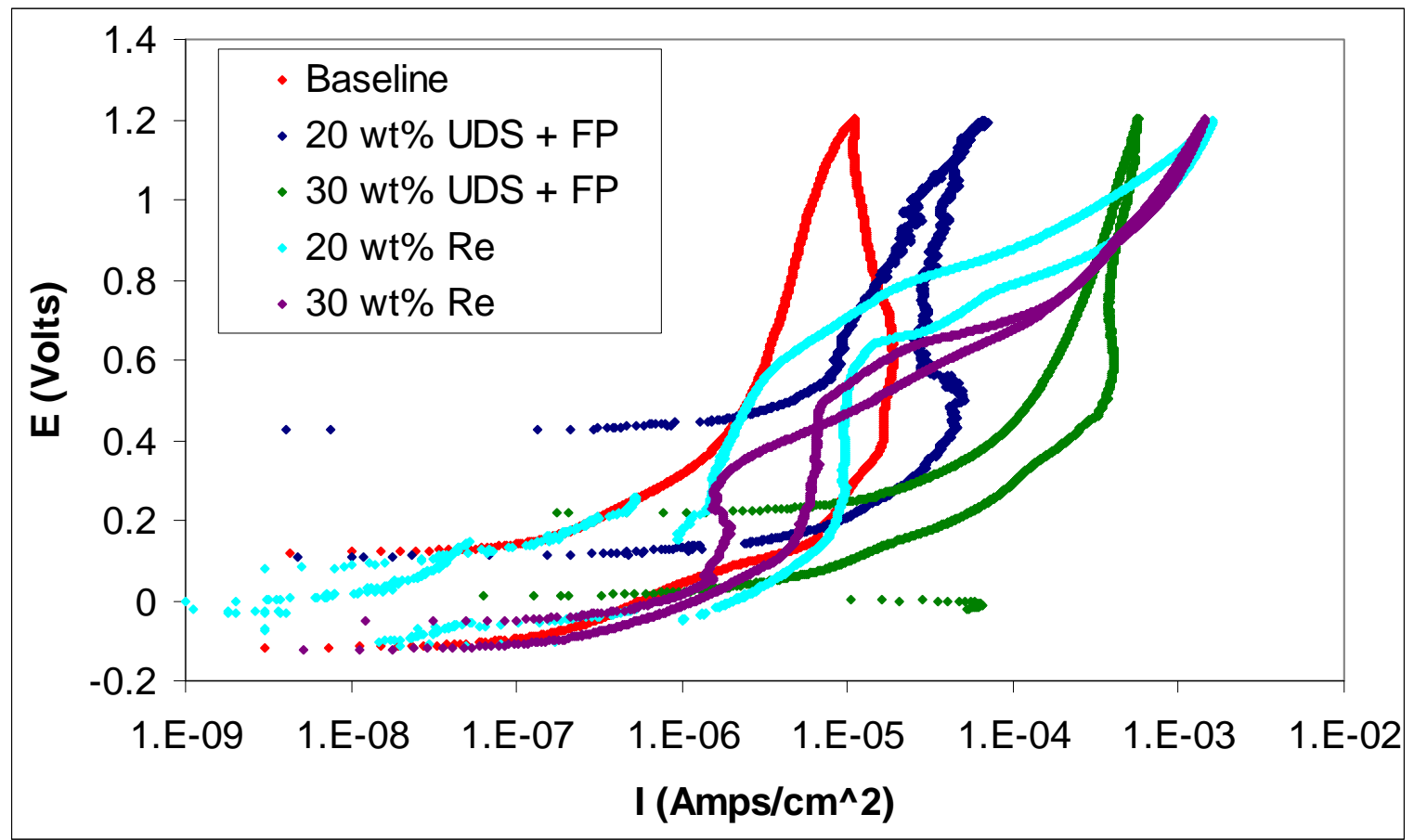

Figure 16. Cyclic Polarization curves for selected waste form specimens at $\mathrm{pH}=2$ conditions.

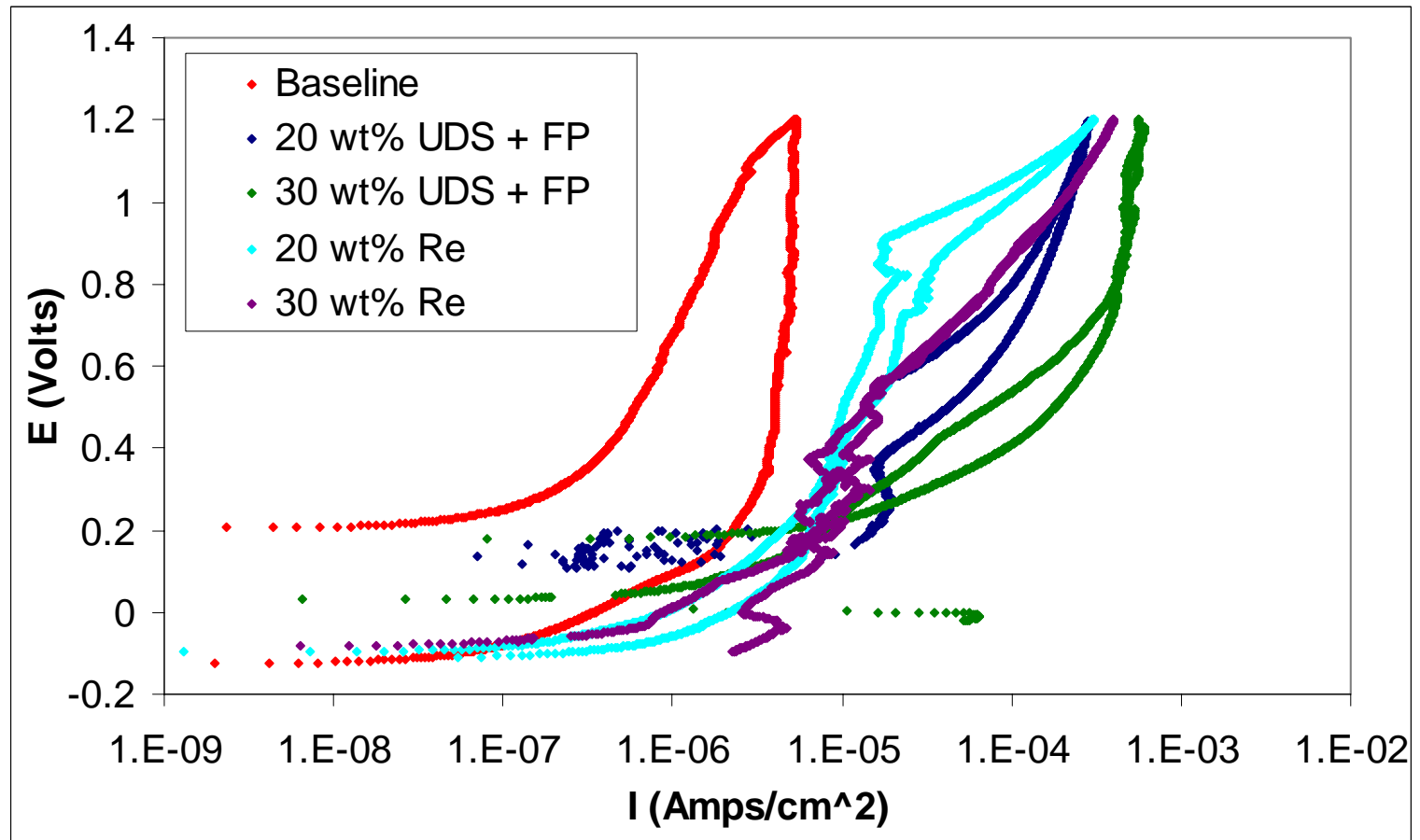

Figure 17. Cyclic Polarization curves for selected waste form specimens at $\mathrm{pH}=4$ conditions. 


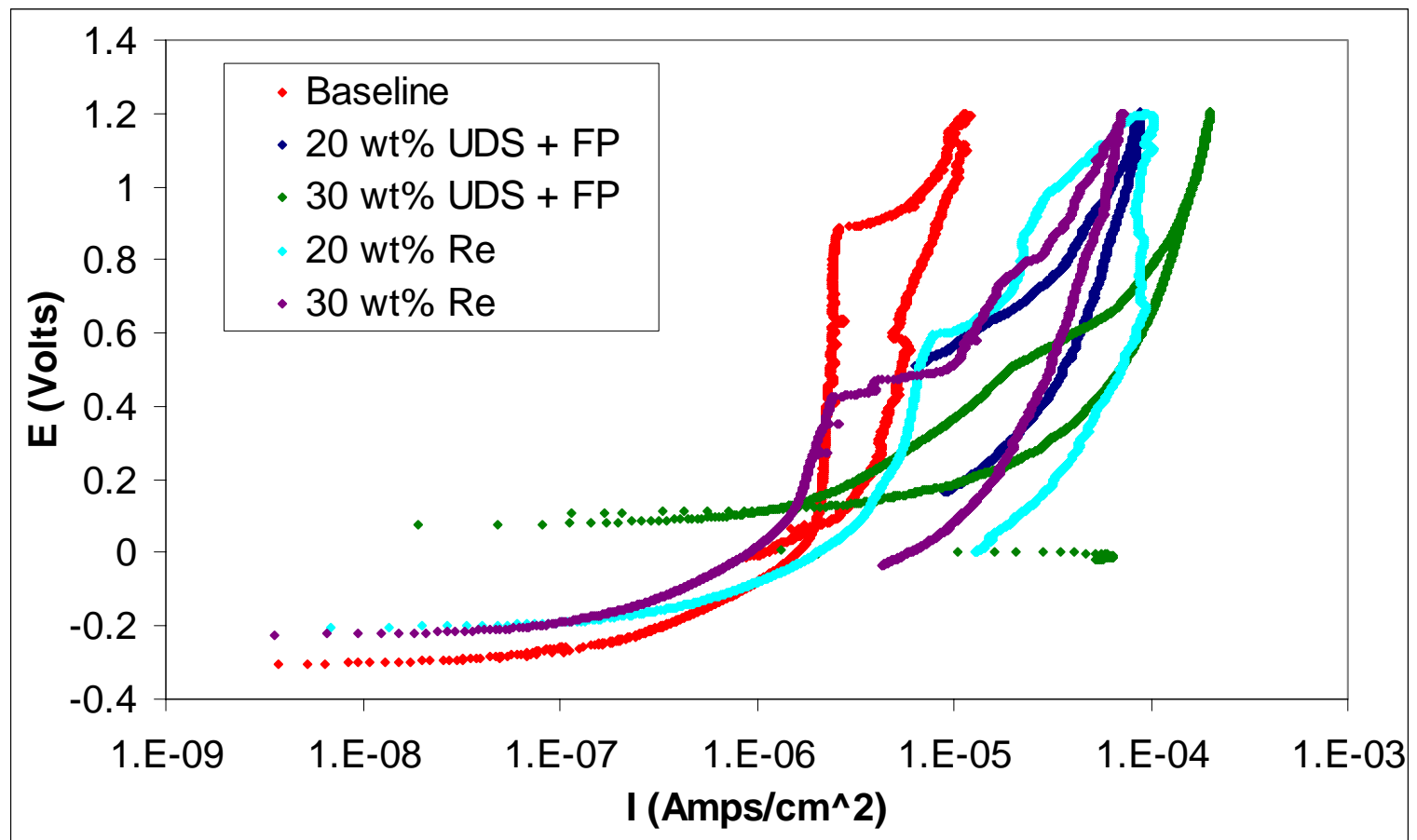

Figure 18. Cyclic Polarization curves for selected waste form specimens at $\mathrm{pH}=10$ conditions.

Table 15. Calculated corrosion rates for selected tested alloys

\begin{tabular}{|c|c|r|r|}
\hline Corrosion Rate um/yr & $\mathbf{p H}=\mathbf{2}$ & $\mathbf{p H}=\mathbf{4}$ & $\mathbf{p H}=\mathbf{1 0}$ \\
\hline Baseline alloy & 4.5592 & 9.1956 & \\
\hline $\mathbf{1 0} \mathbf{w t} \%$ UDS + TMFP & & & \\
\hline $\mathbf{2 0} \mathbf{w t} \%$ UDS + TMFP & 54.922 & --- & \\
\hline $\mathbf{3 0} \mathbf{w t} \%$ UDS + TMFP & 27.735 & 20.1 & 16.007 \\
\hline $\mathbf{1 0} \mathbf{w t} \% \mathbf{R e}$ & --- & 3.7395 & 5.0315 \\
\hline $\mathbf{2 0} \mathbf{w t} \% \mathbf{R e}$ & 3.4914 & 4.9623 & 3.843 \\
\hline $\mathbf{3 0} \mathbf{w t} \% \mathbf{R e}$ & & & \\
\hline $\mathbf{4 0} \mathbf{w t} \% \mathbf{R e}$ & & & \\
\hline
\end{tabular}

\section{CONCLUSIONS AND SUMMARY}

A zirconium-based alloy for immobilization of Zircaloy cladding hulls, Undissolved Solids (UDS), Technicium (Tc) metal and Transition Metal Fission Products (TMFP) waste stream materials from separations processes has been developed, and initial characterization of the phase assemblage and composition, and electrochemical testing under aqueous conditions has been completed for the waste form with various levels of surrogate waste species.

Constituents of a Zr-based alloy of 70Zr-20Cu-10Fe (baseline alloy) were melted with surrogate (UDS + TMFP) species, and with surrogate Tc (Re) species up to $50 \mathrm{wt} \%$ at a furnace melt process temperature of $1300^{\circ} \mathrm{C}$. At these conditions, $30 \mathrm{wt} \% \mathrm{UDS}+\mathrm{TMFP}$ and $40 \mathrm{wt} \% \mathrm{Tc}(\mathrm{Re})$ were incorporated into the alloy.

Characterization of the phase assemblage was performed to identify the phase structure and composition, and an assessment of the partitioning of waste species in the assemblage was performed. Zirconium and 
iron formed intermetallic phases with the surrogate UDS + TMFP elements, as expected. However, the identified phases did not agree completely with phase formation suggested by the binary phase diagrams of the target species with $\mathrm{Zr}$ and $\mathrm{Fe}$. Cu metal was not expected to alloy with any of the target waste species; however, there were $\mathrm{Cu}$-rich intermetallics formed that played a role in sequestering certain waste elements.

Electrochemical testing was performed to evaluate corrosion behavior. Cyclic polarization test results indicate that the baseline alloy passivates at $\mathrm{pH} 2-10$. The baseline alloys with the incorporated surrogate waste stream elements, UDS + TMFP, also show passivation behavior at lower $\mathrm{pH}(2,4)$ conditions and started to show reduced tendency for passivation at higher $\mathrm{pH}$ levels (10). The corrosion rates of the baseline with surrogate UDS + TMFP alloys are greatest in the low $\mathrm{pH}$ (2) solution; whereas the corrosion rates for baseline with surrogate Tc alloys increased slightly with $\mathrm{pH}$.

\section{SUGGESTED FUTURE WORK}

An iron-based alloy that provides for minimum alloying materials additions to the waste stream materials is the leading metal waste form to be further developed under the Waste Form Campaign under the GNEP program [6]. This iron-based alloy, termed the Minimum Additives Waste Stabilization (MAWS) alloy system would provide significantly less volume of metallic waste to immobilize the UDS, Tc, and TMFP species. The zirconium-based alloy described in this present report provides an alternative to the MAWS alloy system for programmatic risk reduction in the Waste Form Campaign.

If the zirconium-based alloy were to be further developed, additional work to further characterize specie partitioning to the phases, and to evaluate congruency of release is recommended to increase the readiness of this candidate alloy. It is also suggested that reduction of TMFP oxides may be possible in a melt process, and investigation of incorporation of the oxide forms of the TMFP and possibly Tc into the MWF could be pursued. Lab and scale-up tests to immobilize the target waste stream materials using actual waste stream materials would ultimately be needed for full readiness of the waste form. 


\section{REFERENCES}

1. U.S. DOE, GNEP, http://www.gnep.energy.gov/gnepProliferationResistantRecycling.html.

2. Gombert II, D., Roach, J. A. et al "Global Nuclear Energy Partnership Integrated Waste Management Strategy Technical and Policy Issues for Implementation," INL/EXT-07-12620, Revision 0, May 2007.

3. Dirk Gombert II, GNEP-WAST-AI-RT-2007-000324, "Global Nuclear Energy Partnership Integrated Waste Management Strategy Waste Treatment Baseline Study,” September 2007.

4. S. M. McDeavitt, D. P. Abraham, and J.Y. Park, "Evaluation of Stainless Steel-Zirconium Alloys as High Level Nuclear Waste Forms," Journal of Nuclear Materials, 257, pp 21-34, 1998.

5. T.M. Adams, M.C. Kane, and H.B. Peacock, "Candidate Systems for a GNEP Metallic Wasteform" WSRC-STI-2007-00484, September 2007.

6. W.L. Ebert, et al., "Combined Metal Waste Form Results," presented from the Metal Waste Form team at the Waste Form Campaign Working Group Meeting, July 9, 2008.

7. Adachi, T. Ohnuki, M., Yoshida, N., Sonobe, T., Kawamura, W., Takeishi, H., Gunji, K., Kimura, T., Suzuki, T., Nakahara, Y., Muromura, T., Kobayashi, Y., Okashita, Ho, and Yamamoto, T, "Dissolution Study of Spent PWR Fuel: Dissolution Behavior and Chemical Properties of Insolvable Residues," Journal of Nuclear Materials, 174, pp. 60-71, 1990.

8. Tracy S. Rudisill, "Decontamination of Spent Fuel Cladding Hulls," GNEP-AFCI-IMPT-MS-2007000192, February 2008.

9. Keiser, Jr. D.D., Abraham, D.P., Richardson, Jr. J.W., "Influence of technetium on the microstructure of a stainless steel-zirconium alloy," Journal of Nuclear Materials, 277, (2000), pp333-338.

10. R. Bonniaud, N. Jacquet-Francillon, A. Jouan, and C. Sombret, Melting Process to Condition Decladding Hulls Generated by the Reprocessing of LWR and FBR Spent Fuels, Scientific Basis for Nuclear Waste Management 3, 1981, pp. 267-74.

11. ASM International, Binary Alloy Phase Diagrams, $2^{\text {nd }}$ edition, Thaddeus B. Massalske, editor-inchief, volumes 1,2,3, December 1990.

12. W.G. Moffatt, The Handbook of Binary Phase Diagram Volume II, Genium Publishing, New York, 1984, p.292.

13. ASM International, Handbook of Ternary Alloy Phase Diagrams Volume 7, P. Villars, A. Prince, and H. Okamoto, editors., January 1997. 